\title{
Fundamentals, Panics, and Bank Distress During the Depression
}

\author{
By Charles W. Calomiris and Joseph R. Mason*
}

\begin{abstract}
We assemble bank-level and other data for Fed member banks to model determinants of bank failure. Fundamentals explain bank failure risk well. The first two Friedman-Schwartz crises are not associated with positive unexplained residual failure risk, or increased importance of bank illiquidity for forecasting failure. The third Friedman-Schwartz crisis is more ambiguous, but increased residual failure risk is small in the aggregate. The final crisis (early 1933) saw a large unexplained increase in bank failure risk. Local contagion and illiquidity may have played a role in pre-1933 bank failures, even though those effects were not large in their aggregate impact. (JEL N22, G21, N12, E32, E5)
\end{abstract}

The central unresolved question about the causes of bank distress during the Depression is the extent to which the waves of bank failures and deposit contraction (which together define bank distress) reflected "fundamental" deterioration in bank health, or alternatively, "panics"

\footnotetext{
* Calomiris: Graduate School of Business, 601 Uris Hall, Columbia University, 3022 Broadway, New York, NY 10027, National Bureau of Economic Research, and American Enterprise Institute (e-mail: cc374@columbia.edu); Mason: LeBow College of Business, Drexel University, 3141 Chestnut Street, Philadelphia, PA 19104, and Wharton Financial Institutions Center (e-mail: jrm27@drexel.edu). We gratefully acknowledge support from the National Science Foundation, the University of Illinois, and the Federal Reserve Bank of St. Louis. In particular, we would like to thank William Dewald, formerly of the St. Louis Fed, and the late William Bryan of the University of Illinois, for facilitating the process of transcribing our data from the original microfilm. Jo Ann Landen, formerly of the Federal Reserve Board library, was instrumental in locating the microfilm of call reports from which bank balance sheets and income statements were assembled. We are also grateful to Jim Coen and his staff at the Columbia Business School library for their help in assembling additional data. Cary Fitzmaurice, Aaron Gersonde, Inessa Love, Jennifer Mack, Barbera Shinabarger, George Williams, and Melissa Williams provided excellent research assistance. We thank Mike Bordo, Barry Eichengreen, Glenn Hubbard, Peter Temin, Elmus Wicker, two anonymous referees, and participants in seminars at the NBER Development of the American Economy Summer Institute meetings, Indiana University, Northwestern University, Tulane University, and the University of Pennsylvania for helpful comments on an earlier draft. This paper is a revised version of "Causes of U.S. Bank Distress During the Depression" (Calomiris and Mason, 2000).
}

or sudden crises of systemic illiquidity that may have forced viable banks to fail. The causes of bank distress are particularly relevant from the perspective of modern macroeconomic theories of the relationship between bank distress and economic fluctuations, and public policy debates about the appropriate responses of central banks to financial crises. To the extent that bank distress was not due to fundamental bank weakness, policy actions to protect threatened banks via Fed or government loans or other assistance might have prevented failures and deposit contraction. If the collapse of the banking system was driven by events within the banking system (rather than shocks to banks from the "real" economy), that would also have important implications for macroeconomic theory-namely, the implication that the financial sector itself can be an important source of shocks, not just a victim or a propagator of shocks (see Douglas W. Diamond and Phillip H. Dybvig, 1983; Franklin Allen and Douglas Gale, 2000; Diamond and Raghuram Rajan, 2002).

The list of fundamental shocks that may have weakened banks is a long and varied one. It includes declines in the value of bank loan portfolios produced by rising default risk in the wake of regional, sectoral, or national macroeconomic shocks to bank borrowers, as well as monetary-policy-induced declines in the prices of the bonds held by banks. There is no doubt that adverse fundamental shocks relevant to bank solvency were contributors to bank distress; the controversy is over the size of these 
fundamental shocks-that is, whether banks experiencing distress were truly insolvent or simply illiquid.

Milton Friedman and Anna J. Schwartz (1963) are the most prominent advocates of the view that many bank failures resulted from unwarranted "panic" and that failing banks were in large measure illiquid rather than insolvent. Friedman and Schwartz attach great importance to the banking crisis of late 1930, which they attribute to a "contagion of fear" that resulted from the failure of a large New York bank, the Bank of United States, which they regard as itself a victim of panic.

They also identify two other banking crises in 1931-from March to August 1931, and from Britain's departure from the gold standard (September 21, 1931) through the end of the year. The fourth and final banking crisis they identify occurred at the end of 1932 and the beginning of 1933, culminating in the nationwide suspension of banks in March. The 1933 crisis and suspension was the beginning of the end of the Depression, but the 1930 and 1931 crises (because they did not result in suspension) were, in Friedman and Schwartz's judgment, important sources of shock to the real economy that turned a recession in 1929 into the Great Depression of 1929-1933.

Friedman and Schwartz's (1963) summary of the aggregate trends for the macroeconomy and the banking sector focuses on the extreme severity of the banking crises (the incidence of bank suspension) and the accompanying declines in deposits and the money multiplier. They argue that Federal Reserve errors of commission (decisions to tighten) and omission (failures to address the problem of banking "panic" and bank illiquidity) were central causes of the economic collapse of the Depression. Our interest is in the second aspect-the question of whether the banking collapses were unwarranted panics that forced solvent but illiquid banks to fail. The Friedman and Schwartz argument is based upon the suddenness of banking distress during the panics that they identify, and the absence of collapses in relevant macroeconomic time series prior to those banking crises (see Charts 27-30 in Friedman and Schwartz, 1963, p. 309). ${ }^{1}$

\footnotetext{
${ }^{1}$ Exaggerated fears of bank insolvency were not the only potential contributors to runs on solvent banks. In the case
}

But there are reasons to question Friedman and Schwartz's view of the exogenous origins of the banking crises of the Depression. As Calomiris and Gary Gorton (1991) show, preDepression panics were moments of temporary confusion about which (of a very small number of banks) were insolvent. In contrast, as Peter Temin (1976) and many others have noted, the bank failures during the Depression marked a continuation of the severe banking sector distress that had gripped agricultural regions throughout the 1920 's. Of the nearly 15,000 bank disappearances that occurred between 1920 and 1933, roughly half predate 1930 . And massive numbers of bank failures occurred during the Depression era outside the crisis windows identified by Friedman and Schwartz (notably, in 1932). Wicker (1996, p. 1) estimates that "[b]etween 1930 and 1932 of the more than 5,000 banks that closed only 38 percent suspended during the first three banking crisis episodes."2 Recent studies of the condition of the Bank of United States indicate that it too was insolvent, not just illiquid, in December 1930 (Joseph Lucia, 1985; Friedman and Schwartz, 1986; Anthony P. O’Brien, 1992;

of the banking crisis of 1933, Barrie A. Wigmore (1987) sees the risk of abandoning the gold standard as an important exogenous motivator of depositor flight from solvent banks. Wigmore emphasizes external currency drain and the expectation of the departure from the gold standard, not concerns over domestic bank solvency, as the precipitating event that led to the March 6 declaration of a national bank holiday. Elmus Wicker (1996) accepts the importance of the external drain in early 1933, but argues that Wigmore underestimates the importance of the regional crisis that gripped midwestern banks (beginning with Michigan banks) in early 1933.

${ }^{2}$ Furthermore, banking distress in the 1930's did not provoke collective action by banks (clearinghouse actions to share risks or suspend convertibility), as had been the case in the pre-Fed era. Friedman and Schwartz argue that "... the existence of the Reserve System prevented concerted restriction ... by reducing the concern of stronger banks, which had in the past typically taken the lead in such a concerted move ... and indirectly, by supporting the general assumption that such a move was made unnecessary by the establishment of the System" (1963, p. 311). Another possibility is that collective action was not warranted (i.e., solvent banks were not threatened by the failures of insolvent banks). Collective action remained feasible, as illustrated by the behavior of Chicago banks in June 1932, but Friedman and Schwartz see these as exceptions. See F. Cyril James (1938) and Calomiris and Mason (1997) for details on the Chicago panic and the role of collective action in resolving it. 
Paul B. Trescott, 1992; Wicker, 1996). So there is some prima facie evidence that the banking distress of the Depression era was more than a problem of panic-inspired depositor flight.

But how can one attribute bank failures during the Depression to fundamentals when Friedman and Schwartz's evidence indicates no prior changes in macroeconomic fundamentals? One possibility is that Friedman and Schwartz omitted important aggregate measures of the state of the economy relevant for bank solvency. For example, measures of commercial distress and construction activity may be useful indicators of fundamental shocks.

A second possibility is that aggregation of fundamentals masks important sectoral, local, and regional shocks that buffeted banks with particular credit or market risks. The most important challenge to Friedman and Schwartz's aggregate view of bank distress during the Depression has come from the work of Wicker $(1980,1996)$. Using a narrative approach similar to that of Friedman and Schwartz, but relying on data disaggregated to the level of the Federal Reserve districts and on local newspaper accounts of banking distress, Wicker argues that it is incorrect to identify the banking crisis of 1930 and the first banking crisis of 1931 as national panics comparable to those of the preFed era. According to Wicker, the proper way to understand the process of banking failure during the Depression is to disaggregate, both by region and by bank, because heterogeneity was very important in determining the incidence of bank failures.

Once one disaggregates, Wicker argues, it becomes apparent that at least the first two of the three banking crises of 1930-1931 identified by Friedman and Schwartz were largely regional affairs. Wicker $(1980,1996)$ argues that the failures of November 1930 reflected regional shocks and the specific risk exposures of a small subset of banks, linked to Nashvillebased Caldwell \& Co., the largest investment bank in the South at the time of its failure. Temin $(1989$, p. 50) reaches a similar conclusion. He argues that the "panic" of 1930 was not really a panic, and that the failure of Caldwell \& Co. and the Bank of United States reflected fundamental weakness in those institutions.

Wicker's analysis of the third banking crisis (beginning September 1931) also shows that bank suspensions were concentrated in a very few locales, although he regards the nationwide increase in the tendency to convert deposits into cash as evidence of a possible nationwide banking crisis in September and October 1931. Wicker agrees with Friedman and Schwartz that the final banking crisis (of 1933), which resulted in universal suspension of bank operations, was nationwide in scope. The banking crisis that culminated in the bank holidays of February-March 1933 resulted in the suspension of at least some bank operations (bank "holidays") for nearly all banks in the country by March 6 .

From the regionally disaggregated perspective of Wicker's findings, the inability to explain the timing of bank failures using aggregate time-series data (which underlay the FriedmanSchwartz view that banking failures were an unwarranted and autonomous source of shock) would not be surprising even if bank failures were entirely due to fundamental insolvency. Failures of banks were local phenomena in 1930 and 1931, and so may have had little to do with national shocks to income, the price level, interest rates, and asset prices.

The unique industrial organization of the American banking industry is of central importance to the Wicker view of the process of bank failure during the Depression. Banks in the United States (unlike banks in other countries) did not operate throughout the country. They were smaller, regionally isolated institutions. In the United States, therefore, large regionspecific shocks might produce a sudden wave of bank failures in specific regions even though no evidence of a shock was visible in aggregate macroeconomic time series (see the cross-country evidence in Ben S. Bernanke and Harold James, 1991, and Richard S. Grossman, 1994).

Microeconomic studies of banking distress have provided some useful evidence on the reactions of individual banks to economic distress, which bears on these macroeconomic debates. Eugene N. White (1984) showed that the failures of banks in 1930 are best explained as a continuation of the agricultural distress of the 1920's, and were traceable to fundamental disturbances in agricultural markets. Calomiris and Mason (1997) studied the Chicago banking panic of June 1932 (a locally isolated phenomenon). They found that the panic resulted only in a temporary unwarranted contraction of deposits; local fundamentals determined both the 
long-run contraction of bank deposits and which Chicago banks failed before and during the panic. Calomiris and Berry Wilson (1998) studied the behavior of New York City banks during the interwar period, and in particular, analyzed the contraction of their lending during the 1930's. They found that banking distress was an informed market response to observable weaknesses in particular banks, traceable to ex ante bank characteristics.

Taken together, these studies suggest that local fundamentals played a large role in generating banking distress during the Depression. From the standpoint of the larger macroeconomic questions that underlie much of the interest in the origins of banking distress during the Depression, however, existing microeconometric contributions suffer from three weaknesses. First, they rely upon limited samples. Analysis of banks in particular locations, or at particular times, may paint a misleading picture of the causes of banking distress for the country as a whole during the Depression. Second, some of the previous microeconomic studies have used sources that contain a limited set of bank characteristics, and which exclude characteristics that are likely to be important in modeling bank distress (as indicated by the results of Calomiris and Mason, 1997, which show the advantage of including a relatively rich set of characteristics).

Third, none of the microeconometric studies has tried to measure the relative importance of fundamentals and "contagion" for explaining bank failures at the regional or national level. This is an important omission. The fact that regional shocks were important (as argued by Wicker and others) does not in itself disprove the Friedman-Schwartz view that runs on banks resulted in large part from panic. Indeed, Wicker-who disputes the existence of nationwide panics in 1930 and early 1931 - argues that local and regional panics contributed to bank failures over and above fundamental regional shocks.

This paper assembles a rich disaggregated data set capable of linking fundamental sources of bank weakness-individual Fed member bank's portfolio and liability structure and condition, and local, regional, and national economic shocks - to the process of bank failure. We construct a survival duration model of banks that relates information about the timing of individual bank failures to the characteristics of individual banks, and to the changing local, regional, and national economic environment in which they operated. A detailed, disaggregated model of the fundamental determinants of bank failure makes possible the evaluation of the relative importance of contagion for generating banking distress.

To summarize our objectives, we seek (1) to gauge the extent to which the attributes of specific banks, in concert with the fundamental local or national shocks that buffeted those banks, can explain the timing and incidence of bank failures, (2) to evaluate the importance of panic or contagion - nationally or locally-as a cause of bank failure during the Depression, and (3) to identify the extent to which particular banking crises were national or regional events.

Our investigation of the causes of banking distress relies upon the fact that the U.S. banking system was geographically fragmented. In most states, banks were not free to operate branches (the so-called "unit" banking restriction). Even in states that permitted branching within the state, branching was often limited, and in all cases, branching was not allowed outside the state. ${ }^{3}$ Geographic fragmentation of banking permits one to identify locationspecific and bank-specific determinants of failure for a large sample of banks, and to investigate whether the failures of banks located nearby affected the probability of a bank's failure (a local contagion effect).

The chief limitation of our data set is that it only covers Fed member banks (national banks plus state-chartered banks that belonged to the Federal Reserve System). Most bank failures during the Depression were nonmember banks, so there is some question as to whether our results offer an adequate portrayal of the experience of all banks. We discuss this issue in more detail in Section I below.

The remainder of this paper is organized as follows. Section I briefly describes the data set and defines and explains the limits of our investigation - that is, why we confine our attention to certain measures of economic performance, and to Fed member banks' behavior. Section II contains our analysis of the causes of

\footnotetext{
${ }^{3}$ See Calomiris (2000) for a review of the history of unit banking restrictions and their costs.
} 
bank failure using data on individual banks. Specifically, in Section II we construct a survival duration model for banks and consider the significance of bank characteristics, shocks to the economic environment, and various measures of "contagion" or "panic" for reducing the probability of bank survival. Section III summarizes our results and concludes.

\section{Data}

The sources and definitions of the data used in our empirical work are discussed in detail in the Data Appendix. Our data set combines data on individual bank characteristics for Fed member banks observed in December 1929 and December 1931 with county-, state-, and national-level data at monthly, quarterly, and annual frequencies. These data permit us to measure bank distress by date of failure at various levels of disaggregation, and to capture a variety of influences on bank distress. Table 1 summarizes the measures of bank characteristics we constructed and the measures we employ to capture variation in the local, regional, and national economic environment.

Tables 2 and 3 provide information about variation over time and across regions in the incidence of bank failure, which we define as bank closure and liquidation. Tables $2 \mathrm{a}$ and $2 \mathrm{~b}$ report semiannual numbers and deposits of Fed member banks that failed, by region. Tables $3 \mathrm{a}$ and $3 b$ express these regional-level measures of bank failure as fractions of total Fed member banks, or total Fed member bank deposits, in each region at the end of 1929 . The data reported in Tables 2 and 3 have not been collected or reported in previous studies (more detailed data are described in Calomiris and Mason, 2000). These data clearly show the remarkable heterogeneity in regional experiences of bank distress and deposit growth during the Depression.

Figures 1-3 report various macroeconomic time series alongside our measure of Fed member banks' conditional failure hazard. These data provide a similar picture of aggregate bank distress over time to the evidence on bank suspension rates in Friedman and Schwartz, and confirm Friedman and Schwartz's view that aggregate macroeconomic indicators provide a poor explanation for the timing of waves of bank failures. The only macroeconomic indica- tor that shows sudden change similar to that of bank failures is the liabilities of failed businesses, and it does not show increases prior to the first three panic episodes identified by Friedman and Schwartz, although it often does move in parallel to bank failure risk. The evidence presented in Tables 2-3 and Figures 1-3 shows that our sample of Fed member banks provides pictures of the timing of total bank failures, the relationship between aggregate bank failures and macroeconomic aggregates, and the regional and temporal distribution of bank failures that are similar to those in Friedman and Schwartz (1963) and Wicker (1996). Visual inspection of aggregate variables indicates that they are not very helpful in predicting the Friedman and Schwartz crisis windows, and the cross-sectional variation emphasized by Wicker's discussion of suspensions at the Fed District level is quite visible in the pattern of bank failures at the state level. These tables and figures provide prima facie evidence for the desirability of disaggregating the analysis of bank failure and examining connections between fundamental determinants of bank weakness and the probability of bank failures.

Despite the fact that the national and regional aggregate time series of suspension rates for all banks coincides with the national and regional average survival hazards for our sample of Fed member banks, the absence of nonmember banks from our sample is an important limitation of our analysis of bank failure, which may matter for more disaggregated results. As of June 30, 1929, nonmember banks comprised 15,797 of the 24,504 banks in existence (of which 7,530 were national banks and 1,177 were state-chartered member banks). Nonmember banks were smaller on average, accounting for 27 percent of total bank deposits. Failure rates were higher for nonmember banks. Nonmember banks fell as a proportion of total banks from 63 percent of the number of banks in June 1929 to 57 percent by June 1933. In Calomiris and Mason (2000), we found that indicators of the condition of Fed member banks within the county were useful indicators of annual suspension rates or deposit growth rates at the county level for all banks. Despite that evidence for the representativeness of Fed member banks, it is possible that nonmember banks had different sensitivities to panic events, so our conclusions 
Table 1 -Variable Definitions

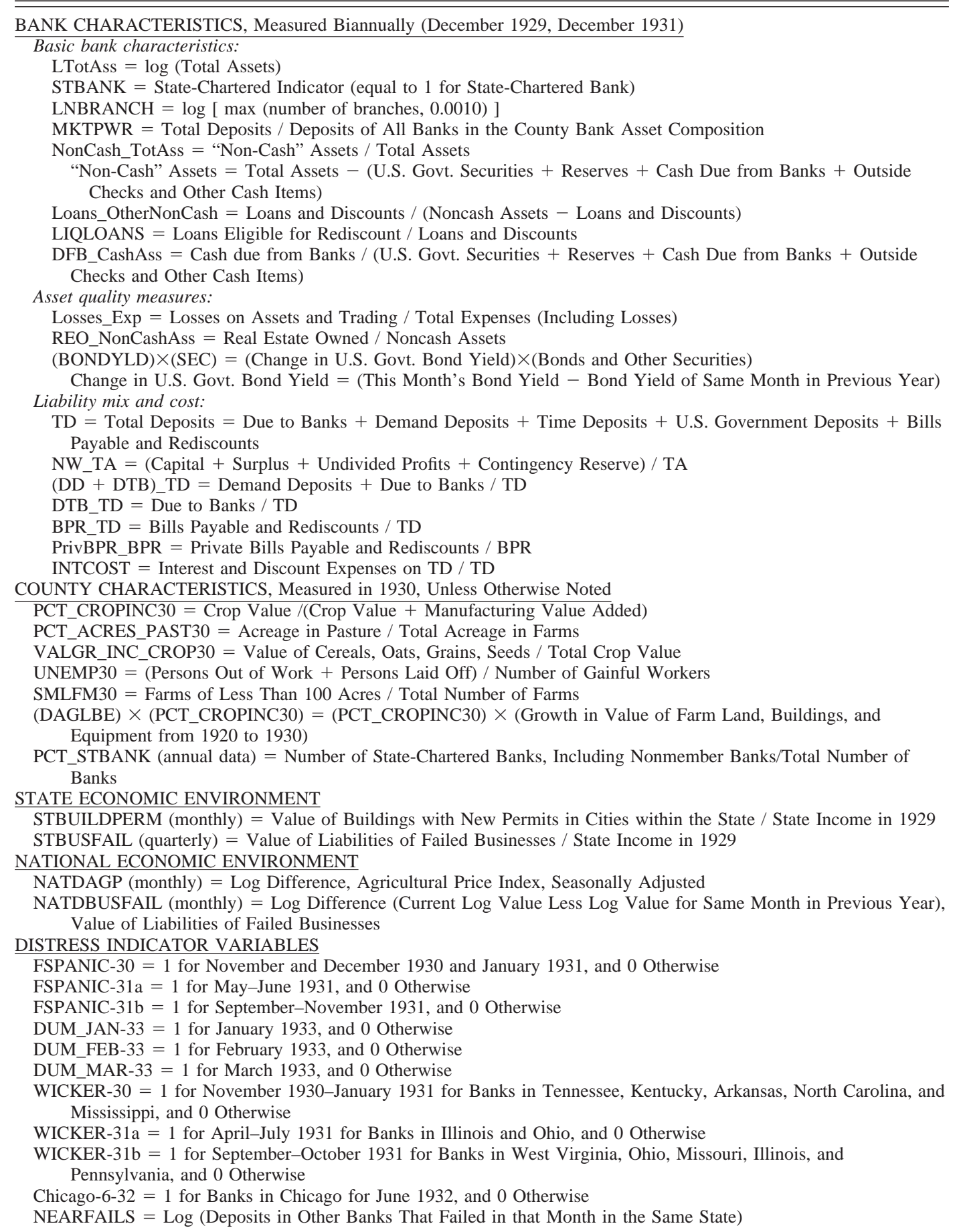

Sources: See Data Appendix. 
Table 2a-Number of Failed Sample Banks, Semiannually, 1930-1933

\begin{tabular}{|c|c|c|c|c|c|c|c|c|}
\hline Region & $1930-1$ & 1930-2 & $1931-1$ & $1931-2$ & $1932-1$ & $1932-2$ & 1933-All & Total \\
\hline Central & 15 & 29 & 45 & 75 & 59 & 25 & 130 & 378 \\
\hline Mid-Atlantic & 7 & 14 & 28 & 51 & 33 & 16 & 58 & 207 \\
\hline Mountain & 8 & 7 & 5 & 16 & 9 & 9 & 18 & 72 \\
\hline New England & 1 & 1 & 4 & 9 & 6 & 0 & 22 & 43 \\
\hline Northwestern & 25 & 30 & 42 & 68 & 37 & 43 & 114 & 359 \\
\hline Pacific & 3 & 3 & 10 & 10 & 23 & 14 & 21 & 84 \\
\hline South Atlantic & 21 & 16 & 21 & 36 & 20 & 9 & 26 & 149 \\
\hline South Central & 28 & 35 & 49 & 42 & 35 & 32 & 50 & 271 \\
\hline Total & 108 & 135 & 204 & 307 & 222 & 148 & 439 & 1,563 \\
\hline
\end{tabular}

Notes: Tables are constructed from 1,716 failed banks in the authors' total data set of 8,470 Federal Reserve Member Banks. Deposits are those recorded from the last available call report prior to failure. Regions are defined as follows: New England contains ME, NH, VT, MA, RI, and CT. Mid-Atlantic contains NY, NJ, and PA. South Atlantic contains MD, DE, DC, VA, WV, NC, SC, GA, and FL. South Central contains KY, TN, AL, MS, AR, OK, LA, and TX. Central contains OH, IL, IN, MI, and WI. Northwestern contains MN, IA, MO, ND, SD, NE, and KS. Mountain contains MT, ID, WY, CO, NM, AZ, UT, and NV. Pacific contains WA, OR, and CA. State-level quarterly versions of these tables are available in Calomiris and Mason, 2000

Table 2b-Deposits of Failed Sample Banks, Semiannually, 1930-1933 (\$ thousands)

\begin{tabular}{lrrrrrrr|r}
\hline \hline Region & $1930-1$ & $1930-2$ & $1931-1$ & $1931-2$ & $1932-1$ & $1932-2$ & $1933-$ All & Total \\
\hline Central & 30,587 & 66,660 & 92,809 & 304,891 & 118,229 & 216,993 & 898,204 & $1,728,374$ \\
Mid-Atlantic & 57,515 & 34,606 & 101,747 & 146,340 & 310,550 & 16,631 & 135,573 & 802,962 \\
Mountain & 5,965 & 1,908 & 1,839 & 6,532 & 2,754 & 12,719 & 16,475 & 48,193 \\
New England & 913 & 1,686 & 9,542 & 49,280 & 137,536 & 0 & 56,228 & 255,184 \\
Northwestern & 29,825 & 21,765 & 24,041 & 36,104 & 33,411 & 32,573 & 116,033 & 293,752 \\
Pacific & 1,018 & 5,521 & 5,067 & 8,318 & 29,195 & 13,686 & 70,224 & 133,029 \\
South Atlantic & 42,184 & 54,850 & 16,535 & 38,854 & 29,555 & 5,814 & 127,409 & 315,200 \\
South Central & 26,140 & 77,399 & 60,867 & 39,933 & 37,865 & 61,537 & 28,311 & 332,051 \\
\hline \multicolumn{1}{c}{ Total } & 194,146 & 264,395 & \multirow{2}{*}{312,447} & 630,252 & 699,095 & 359,953 & $1,448,457$ & $3,908,746$ \\
\hline
\end{tabular}

Note: See notes for Table $2 \mathrm{a}$.

below about Fed member banks may not hold for nonmember banks.

\section{Modeling Bank Failure: Fundamentals and Contagion}

Our bank failure data, which track the specific dates of each Fed member bank failure, allow us to model each bank's daily failure hazard as a function of various fundamentals, including bank-specific variables observed at earlier call report dates, county characteristics, and state- and national-level time series observed at relatively high frequency. All survival duration models we report are estimated using the log-logistic distribution. Detailed descriptions of the survival duration methodology can be found in Nicholas M. Kiefer (1988), Tony Lancaster (1990), and Guido W. Imbens (1994).
One of the advantages of the survival hazard model is its flexibility in using data observed at different levels of aggregation and different frequencies. County-level variables (which are only observed once during the sample period) exert a constant effect on the hazard rate, bankspecific variables (observed biannually at call report dates) affect the hazard rate for two years, and state- and national-level monthly or quarterly series affect the hazard rate on a monthly or quarterly basis.

Our model of the determinants of failure starts with many of the same bank-level determinants that were found to be useful in Calomiris and Mason (1997) to explain bank failures during the Chicago panic of June 1932. Our model of bank failures throughout the country over several years differs, however, from that earlier paper (which focused on failures 
Table 3a-Number of Failed Sample Banks, Semiannually, 1930-1933, as Percent of Total Number of Sample Banks, 1929

\begin{tabular}{lccccccc|r}
\hline \hline Region & $1930-1$ & $1930-2$ & $1931-1$ & $1931-2$ & $1932-1$ & $1932-2$ & $1933-$ All & Total \\
\hline Central & 0.27 & 0.53 & 0.81 & 1.36 & 1.07 & 0.45 & 2.35 & 6.85 \\
Mid-Atlantic & 0.23 & 0.46 & 0.92 & 1.67 & 1.08 & 0.52 & 1.90 & 6.77 \\
Mountain & 1.01 & 0.88 & 0.63 & 2.01 & 1.13 & 1.13 & 2.26 & 9.05 \\
New England & 0.15 & 0.15 & 0.59 & 1.32 & 0.88 & 0.00 & 3.22 & 6.30 \\
Northwestern & 0.40 & 0.47 & 0.66 & 1.07 & 0.58 & 0.68 & 1.80 & 5.67 \\
Pacific & 0.31 & 0.31 & 1.02 & 1.02 & 2.34 & 1.43 & 2.14 & 8.55 \\
South Atlantic & 0.89 & 0.68 & 0.89 & 1.53 & 0.85 & 0.38 & 1.10 & 6.32 \\
South Central & 0.64 & 0.80 & 1.12 & 0.96 & 0.80 & 0.73 & 1.15 & 6.22 \\
\hline \multicolumn{1}{c}{ Total } & 0.45 & 0.56 & 0.84 & 1.27 & 0.92 & 0.61 & 1.82 & 6.47 \\
\hline
\end{tabular}

Notes: Tables are constructed from 1,716 failed banks in the authors' total data set of 8,470 Federal Reserve Member Banks. Deposits are those recorded from the last available call report prior to failure. Regions are defined as follows: New England contains ME, NH, VT, MA, RI, and CT. Mid-Atlantic contains NY, NJ, and PA. South Atlantic contains MD, DE, DC, VA, WV, NC, SC, GA, and FL. South Central contains KY, TN, AL, MS, AR, OK, LA, and TX. Central contains OH, IL, IN, MI, and WI. Northwestern contains MN, IA, MO, ND, SD, NE, and KS. Mountain contains MT, ID, WY, CO, NM, AZ, UT, and NV. Pacific contains WA, OR, and CA. State-level quarterly versions of these tables are available in Calomiris and Mason, 2000.

Table 3b-Deposits of Failed Sample Banks, Semiannually, 1930-1933, as Percent of Total Deposits in Sample Banks, 1929

\begin{tabular}{lccccccr|r}
\hline \hline Region & $1930-1$ & $1930-2$ & $1931-1$ & $1931-2$ & $1932-1$ & $1932-2$ & $1933-$ All & Total \\
\hline Central & 0.30 & 0.64 & 0.90 & 2.94 & 1.14 & 2.09 & 8.67 & 16.68 \\
Mid-Atlantic & 0.28 & 0.17 & 0.49 & 0.71 & 1.50 & 0.08 & 0.65 & 3.87 \\
Mountain & 0.72 & 0.23 & 0.22 & 0.79 & 0.33 & 1.54 & 2.00 & 5.84 \\
New England & 0.03 & 0.05 & 0.30 & 1.52 & 4.25 & 0.00 & 1.74 & 7.89 \\
Northwestern & 0.69 & 0.51 & 0.56 & 0.84 & 0.78 & 0.76 & 2.70 & 6.83 \\
Pacific & 0.02 & 0.12 & 0.11 & 0.19 & 0.66 & 0.31 & 1.58 & 3.00 \\
South Atlantic & 1.49 & 1.94 & 0.58 & 1.37 & 1.05 & 0.21 & 4.51 & 11.15 \\
South Central & 0.69 & 2.04 & 1.61 & 1.05 & 1.00 & 1.62 & 0.75 & 8.76 \\
\hline \multicolumn{1}{c}{ Total } & 0.38 & 0.52 & 0.61 & 1.24 & 1.37 & 0.71 & 2.84 & 7.67 \\
\hline
\end{tabular}

Note: See notes for Table $3 \mathrm{a}$.

occurring in one city during a brief time interval); in the empirical analysis here we include county-level, state-level, and national-level variables in addition to bank-specific characteristics. Our sample period for dating bank failures is from January 1930 to December 1933, and our fundamentals (on which the predictions of survival or failure are based) are observed from January 1930 through March 1933.

Our explanatory variables are expressed as ratios (rather than log ratios) to avoid omitting from the sample observations with a value of zero. In results not reported here, we defined our regressors as log ratios, and this transformation did not affect our results much, but did reduce our sample size. For the high-frequency statelevel and national-level variables we included only one lagged value of each, based on some experimentation to find the lag length with the greatest explanatory power. Below we report results using lags of five months for state-level building permits, national-level agricultural prices, and national-level liabilities of failed businesses, and three quarters for state-level liabilities of failed businesses. We also experimented with using moving averages of these variables. The results described below for the influence of other variables are robust to variation in the specific lag structures of the highfrequency variables. The definitions of the variables used in the regressions are given in Table 1 and summary statistics for these variables are provided in Table 4.

Table 5 ( $\mathrm{a}$ and $\mathrm{b}$ ) presents survival duration 


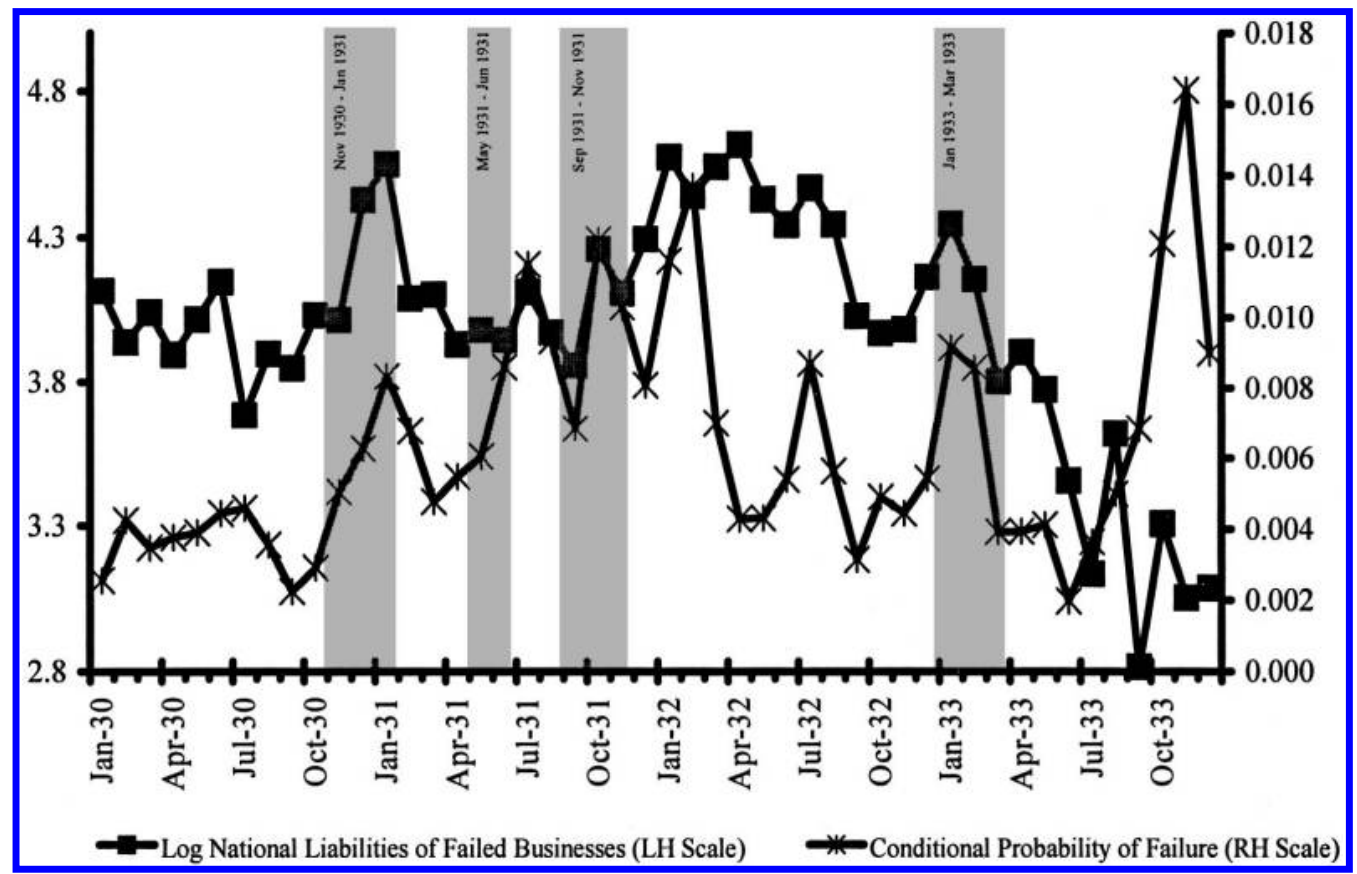

Figure 1. Liabilities of Failed Business and Failure Probability, January 1930-December 1933

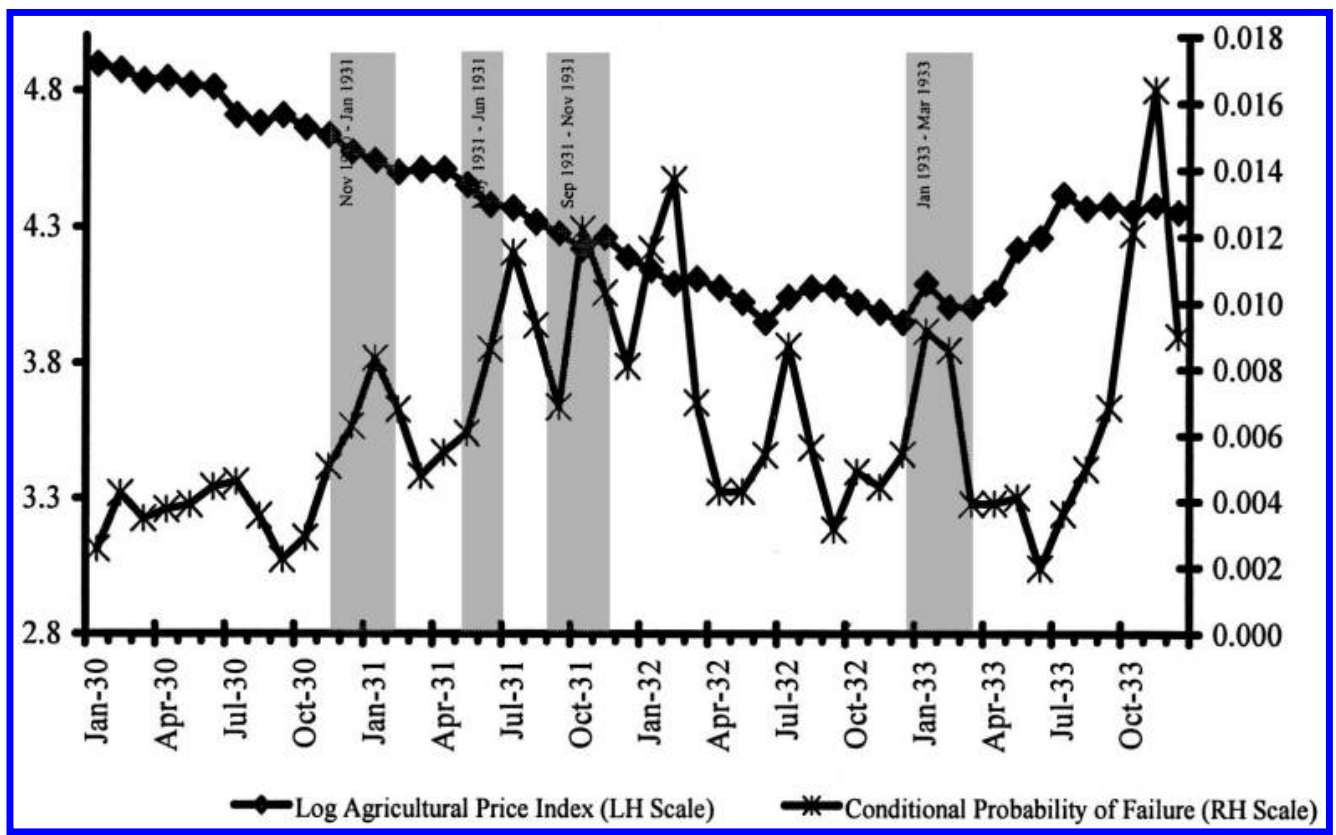

Figure 2. Agricultural Price Index and Failure Probability, January 1930-December 1933

results for the period January 1930 through March 1933. Including bank failures in 1933 in our study posed a problem that required us to exercise judgment about the "correct" timing of the failure of banks. Bank holidays were declared at the state and national levels in February 


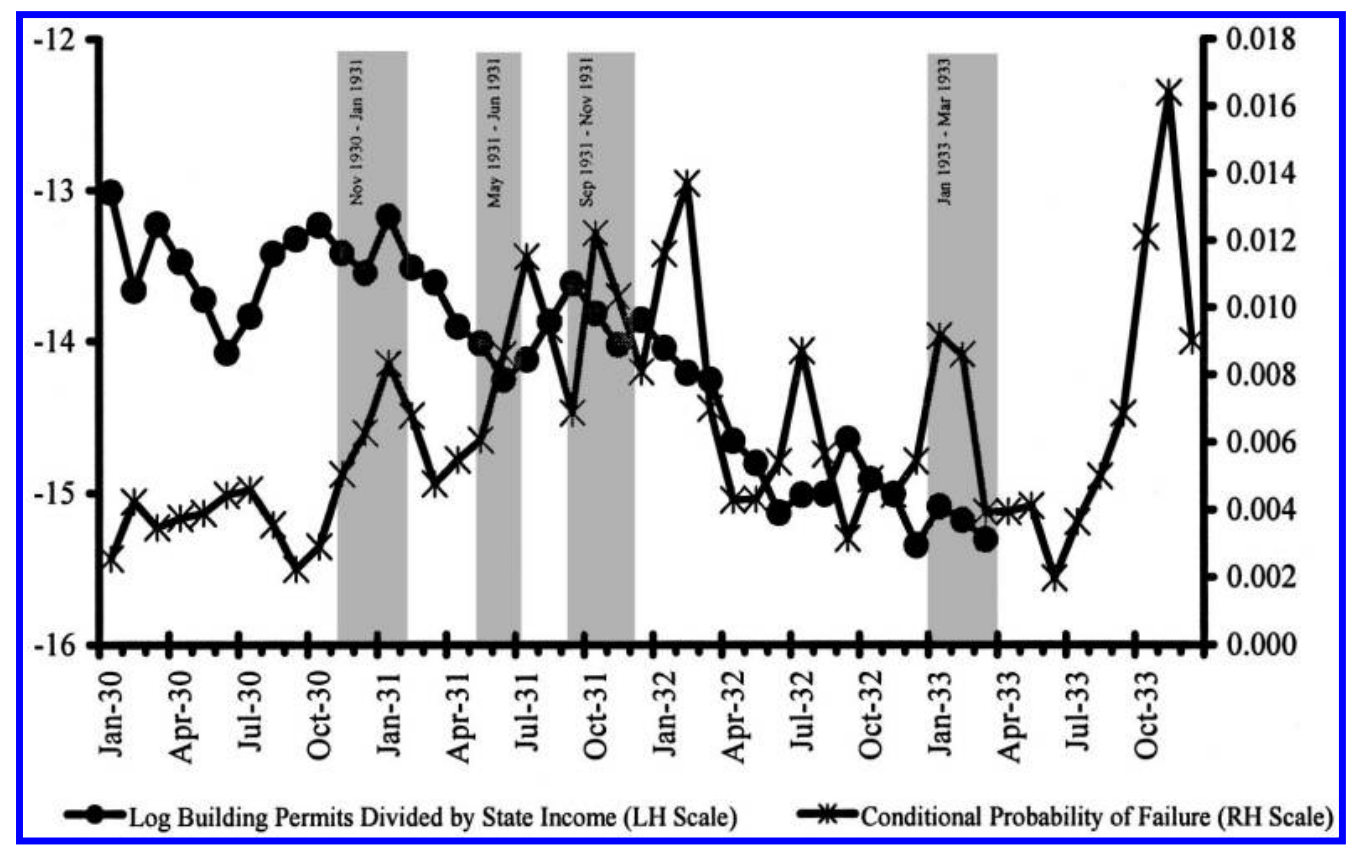

Figure 3. Building Permits and Failure Probability, January 1930-December 1933

and March 1933, which entailed the partial suspension of bank operations for periods of time. Many banks failed during and immediately after the bank holidays. Some banks that did not reopen in March 1933 after suspension remained in a state of regulatory limbo for several months. Many of these banks failed in late 1933 after the regulators and the Reconstruction Finance Corporation (RFC) decided not to approve them for membership in the Federal Deposit Insurance Corporation (FDIC), which began operation in January 1934. The decision to permit banks to reopen sometimes followed approval of assistance from the RFC, and Mason (2001a) finds empirical evidence that preferred stock assistance from the RFC (which began in 1933) did help banks to avoid failure.

Thus the meaning and the timing of bank failures become less clear after February 1933. In particular, some banks that officially failed after March 1933 could be deemed reasonably to have failed in March, and some banks that did not fail officially could be deemed to have failed in March but been rescued by the RFC's new preferred stock program. We experimented with many alternative ways of dealing with the problem of the bank holidays.
In our survival analysis reported below, we truncate both the determinants of failure and the observed failure dates in March 1933. We identify only those banks that officially failed in March as March failures. We also tried several alternative approaches to dealing with the problem of bank holidays. One alternative approach would be to assume that the banks that officially failed between April and December 1933 had actually failed in March 1933. The results for that approach are also similar to those reported below, except that (by construction) there is a large and significant residual for the month of March 1933. We chose to report the first version over this alternative approach because we think that despite its limitations, the first approach distinguishes to some extent between banks that failed in March and those that failed later in 1933, which were arguably stronger. Another alternative approach is to truncate all observations of regressors and failures in January 1933. The coefficients derived for the determinants of failure using that approach are very similar to those we report below. The problem with that third approach is that it does not permit us to examine whether there are unexplained residual failures during the alleged panic of early 1933 
Table 4-Summary Statistics

\begin{tabular}{|c|c|c|c|c|c|}
\hline Variable & $\mathrm{N}$ & Mean & $\begin{array}{r}\text { Standard } \\
\text { deviation }\end{array}$ & Minimum & Maximum \\
\hline \multicolumn{6}{|l|}{ Survival Model (Full Sample) } \\
\hline \multicolumn{6}{|l|}{ Dependent variable } \\
\hline Log(DAYS UNTIL FAILURE) & 269,683 & 5.913 & 1.320 & 0.000 & 7.078 \\
\hline MONTHLY BANK FAILURE RATE & 269,683 & 0.005 & 0.068 & 0.000 & 1.000 \\
\hline \multicolumn{6}{|l|}{ Bank data, December 31, 1929} \\
\hline LTotAss & 7,553 & 13.974 & 1.265 & 10.960 & 21.312 \\
\hline STBANK & 7,553 & 0.112 & 0.316 & 0.000 & 1.000 \\
\hline LNBRANCH & 7,553 & -8.858 & 1.861 & -9.210 & 4.934 \\
\hline MKTPWR & 7,553 & 0.993 & 0.067 & 0.038 & 1.000 \\
\hline NonCash_TotAss & 7,553 & 0.766 & 0.107 & 0.064 & 0.965 \\
\hline Loans_OtherNonCash & 7,553 & 0.744 & 0.186 & 0.030 & 0.997 \\
\hline LIQLOANS & 7,553 & 0.284 & 0.216 & 0.000 & 0.999 \\
\hline Losses_Exp & 7,553 & 0.165 & 0.145 & 0.000 & 0.911 \\
\hline REO_NonCash & 7,553 & 0.013 & 0.025 & 0.000 & 0.340 \\
\hline$(\mathrm{BONDYLD}) \times(\mathrm{SEC})$ & 7,553 & -0.007 & 0.004 & -0.023 & 0.000 \\
\hline$(\mathrm{DD}+\mathrm{DTB}) \_\mathrm{TD}$ & 7,553 & 0.520 & 0.229 & 0.000 & 1.000 \\
\hline DTB_TD & 7,553 & 0.033 & 0.061 & 0.000 & 0.748 \\
\hline DFB_CashAss & 7,553 & 0.281 & 0.172 & 0.000 & 1.000 \\
\hline BPR_TD & 7,553 & 0.028 & 0.049 & 0.000 & 0.504 \\
\hline PrivBPR_BPR & 7,553 & 0.052 & 0.165 & 0.000 & 0.993 \\
\hline NW_TA ${ }^{-}$ & 7,553 & 0.149 & 0.061 & 0.031 & 0.601 \\
\hline INTCOST & 7,553 & 0.011 & 0.010 & 0.000 & 0.598 \\
\hline \multicolumn{6}{|l|}{ Bank data, December 31, 1931} \\
\hline LTotAss & 6,857 & 13.887 & 1.325 & 10.752 & 21.197 \\
\hline STBANK & 6,857 & 0.126 & 0.332 & 0.000 & 1.000 \\
\hline LNBRANCH & 6,857 & -8.856 & 1.872 & -9.210 & 4.934 \\
\hline MKTPWR & 6,857 & 0.990 & 0.082 & 0.026 & 1.000 \\
\hline NonCash_TotAss & 6,857 & 0.760 & 0.109 & 0.130 & 0.978 \\
\hline Loans_OtherNonCash & 6,857 & 0.701 & 0.192 & 0.015 & 0.997 \\
\hline LIQLOANS & 6,857 & 0.253 & 0.198 & 0.000 & 0.999 \\
\hline Losses_Exp & 6,857 & 0.298 & 0.203 & 0.000 & 0.926 \\
\hline REO_NonCash & 6,857 & 0.014 & 0.024 & 0.000 & 0.385 \\
\hline$($ BONDYLD) $\times($ SEC $)$ & 6,857 & 0.080 & 0.043 & 0.001 & 0.258 \\
\hline$(\mathrm{DD}+\mathrm{DTB}) \_\mathrm{TD}$ & 6,857 & 0.467 & 0.233 & 0.000 & 1.000 \\
\hline DTB_TD & 6,857 & 0.028 & 0.055 & 0.000 & 0.683 \\
\hline DFB_CashAss & 6,857 & 0.244 & 0.171 & 0.000 & 1.000 \\
\hline BPR_TD & 6,857 & 0.048 & 0.072 & 0.000 & 0.588 \\
\hline PrivBPR_BPR & 6,857 & 0.069 & 0.180 & 0.000 & 1.000 \\
\hline NW_TA & 6,857 & 0.166 & 0.069 & 0.010 & 0.635 \\
\hline INTCOST & 6,857 & 0.012 & 0.019 & 0.000 & 0.995 \\
\hline \multicolumn{6}{|l|}{ Distress variables } \\
\hline FSPANIC-30 & 269,683 & 0.081 & 0.272 & 0.000 & 1.000 \\
\hline FSPANIC-31a & 269,683 & 0.052 & 0.222 & 0.000 & 1.000 \\
\hline FSPANIC-31b & 269,683 & 0.075 & 0.263 & 0.000 & 1.000 \\
\hline DUM_JAN-33 & 269,683 & 0.023 & 0.151 & 0.000 & 1.000 \\
\hline DUM_FEB-33 & 269,683 & 0.023 & 0.151 & 0.000 & 1.000 \\
\hline DUM_MAR-33 & 269,683 & 0.023 & 0.150 & 0.000 & 1.000 \\
\hline (FSPANIC-30) × (DFB_CashAss) & 269,683 & 0.023 & 0.091 & 0.000 & 1.000 \\
\hline$($ FSPANIC-31a) $\times$ (DFB_CashAss) & 269,683 & 0.015 & 0.074 & 0.000 & 1.000 \\
\hline$($ FSPANIC-31b) $\times$ (DFB_CashAss) & 269,683 & 0.021 & 0.088 & 0.000 & 1.000 \\
\hline WICKER-30 & 269,683 & 0.003 & 0.054 & 0.000 & 1.000 \\
\hline WICKER-31a & 269,683 & 0.008 & 0.090 & 0.000 & 1.000 \\
\hline WICKER-31b & 269,683 & 0.006 & 0.079 & 0.000 & 1.000 \\
\hline (WICKER-30) $\times$ (DFB_CashAss $)$ & 269,683 & 0.001 & 0.021 & 0.000 & 1.000 \\
\hline (WICKER-31a) $\times$ (DFB_CashAss) & 269,683 & 0.002 & 0.025 & 0.000 & 1.000 \\
\hline (WICKER-31b) $\times$ (DFB_CashAss) & 269,683 & 0.001 & 0.021 & 0.000 & 1.000 \\
\hline Chicago-6-32 & 269,683 & 0.000 & 0.015 & 0.000 & 1.000 \\
\hline NEARFAILS & 269,683 & 0.972 & 15.235 & -16.118 & 20.026 \\
\hline
\end{tabular}


TABLE 4-Continued

\begin{tabular}{|c|c|c|c|c|c|}
\hline Variable & $\mathrm{N}$ & Mean & $\begin{array}{r}\text { Standard } \\
\text { deviation }\end{array}$ & Minimum & Maximum \\
\hline \multicolumn{6}{|l|}{ Survival Model (215 City Sample) } \\
\hline Log(DAYS UNTIL FAILURE) & 53,032 & 5.922 & 1.317 & 0.000 & 7.078 \\
\hline MONTHLY BANK FAILURE RATE & 53,032 & 0.004 & 0.065 & 0.000 & 1.000 \\
\hline \multicolumn{6}{|l|}{ Bank data, December 31, 1929} \\
\hline LTotAss & 1,470 & 15.057 & 1.506 & 11.645 & 20.862 \\
\hline STBANK & 1,470 & 0.196 & 0.397 & 0.000 & 1.000 \\
\hline LNBRANCH & 1,470 & -7.970 & 3.342 & -9.210 & 4.934 \\
\hline MKTPWR & 1,470 & 0.974 & 0.124 & 0.044 & 1.000 \\
\hline NonCash_TotAss & 1,470 & 0.786 & 0.097 & 0.245 & 0.965 \\
\hline Loans_OtherNonCash & 1,470 & 0.727 & 0.175 & 0.030 & 0.996 \\
\hline LIQLOANS & 1,470 & 0.189 & 0.172 & 0.000 & 0.980 \\
\hline Losses_Exp & 1,470 & 0.143 & 0.123 & 0.000 & 0.799 \\
\hline REO_NonCash & 1,470 & 0.007 & 0.014 & 0.000 & 0.121 \\
\hline$(\mathrm{BONDYLD}) \times(\mathrm{SEC})$ & 1,470 & -0.007 & 0.004 & -0.022 & 0.000 \\
\hline (DD + DTB)_TD & 1,470 & 0.511 & 0.215 & 0.000 & 1.000 \\
\hline DTB_TD & 1,470 & 0.058 & 0.082 & 0.000 & 0.559 \\
\hline DFB_CashAss & 1,470 & 0.256 & 0.162 & 0.000 & 1.000 \\
\hline BPR_TD & 1,470 & 0.029 & 0.045 & 0.000 & 0.294 \\
\hline PrivBPR_BPR & 1,470 & 0.058 & 0.170 & 0.000 & 0.993 \\
\hline NW_TA & 1,470 & 0.148 & 0.065 & 0.045 & 0.601 \\
\hline INTCOST & 1,470 & 0.012 & 0.006 & 0.000 & 0.151 \\
\hline \multicolumn{6}{|l|}{ Bank data, December 31, 1931} \\
\hline LTotAss & 1,383 & 15.004 & 1.570 & 11.462 & 20.720 \\
\hline STBANK & 1,383 & 0.205 & 0.404 & 0.000 & 1.000 \\
\hline LNBRANCH & 1,383 & -7.976 & 3.352 & -9.210 & 4.934 \\
\hline MKTPWR & 1,383 & 0.961 & 0.159 & 0.037 & 1.000 \\
\hline NonCash_TotAss & 1,383 & 0.764 & 0.110 & 0.237 & 0.962 \\
\hline Loans_OtherNonCash & 1,383 & 0.678 & 0.177 & 0.015 & 0.993 \\
\hline LIQLOAANS & 1,383 & 0.161 & 0.143 & 0.000 & 0.998 \\
\hline Losses_Exp & 1,383 & 0.306 & 0.200 & 0.000 & 0.926 \\
\hline REO_NonCash & 1,383 & 0.010 & 0.016 & 0.000 & 0.144 \\
\hline$($ BONDYLD) $\times($ SEC $)$ & 1,383 & 0.080 & 0.042 & 0.001 & 0.239 \\
\hline$(\mathrm{DD}+\mathrm{DTB}) \_\mathrm{TD}$ & 1,383 & 0.454 & 0.223 & 0.000 & 1.000 \\
\hline DTB_TD & 1,383 & 0.053 & 0.077 & 0.000 & 0.589 \\
\hline DFB_CashAss & 1,383 & 0.219 & 0.162 & 0.000 & 0.877 \\
\hline BPR_TD & 1,383 & 0.044 & 0.063 & 0.000 & 0.376 \\
\hline PrivBPR_BPR & 1,383 & 0.088 & 0.207 & 0.000 & 0.956 \\
\hline NW_TA & 1,383 & 0.159 & 0.070 & 0.010 & 0.635 \\
\hline INTCOST & 1,383 & 0.013 & 0.035 & 0.000 & 0.995 \\
\hline \multicolumn{6}{|l|}{ Distress variables } \\
\hline FSPANIC-30 & 53,032 & 0.079 & 0.271 & 0.000 & 1.000 \\
\hline FSPANIC-31a & 53,032 & 0.051 & 0.221 & 0.000 & 1.000 \\
\hline FSPANIC-31b & 53,032 & 0.074 & 0.262 & 0.000 & 1.000 \\
\hline DUM_JAN-33 & 53,032 & 0.024 & 0.152 & 0.000 & 1.000 \\
\hline DUM_FEB-33 & 53,032 & 0.024 & 0.152 & 0.000 & 1.000 \\
\hline DUM_MAR-33 & 53,032 & 0.023 & 0.151 & 0.000 & 1.000 \\
\hline (FSPANIC-30) × (DFB_CashAss) & 53,032 & 0.020 & 0.083 & 0.000 & 1.000 \\
\hline (FSPANIC-31a) $\times$ (DFB_CashAss) & 53,032 & 0.013 & 0.067 & 0.000 & 1.000 \\
\hline$($ FSPANIC-31b) $\times$ (DFB_CashAss) & 53,032 & 0.019 & 0.080 & 0.000 & 1.000 \\
\hline WICKER-30 & 53,032 & 0.001 & 0.036 & 0.000 & 1.000 \\
\hline WICKER-31a & 53,032 & 0.008 & 0.088 & 0.000 & 1.000 \\
\hline WICKER-31b & 53,032 & 0.007 & 0.081 & 0.000 & 1.000 \\
\hline (WICKER-30) $\times$ (DFB_CashAss $)$ & 53,032 & 0.000 & 0.013 & 0.000 & 0.649 \\
\hline (WICKER-31a) $\times$ (DFB_CashAss) & 53,032 & 0.002 & 0.027 & 0.000 & 1.000 \\
\hline (WICKER-31b) $\times$ (DFB_CashAss) & 53,032 & 0.001 & 0.020 & 0.000 & 1.000 \\
\hline Chicago-6-32 & 53,032 & 0.001 & 0.033 & 0.000 & 1.000 \\
\hline NEARFAILS & 53,032 & 0.729 & 15.422 & -16.118 & 20.026 \\
\hline
\end{tabular}


TABLE 4-Continued

\begin{tabular}{|c|c|c|c|c|c|}
\hline Variable & $\mathrm{N}$ & Mean & $\begin{array}{l}\text { Standard } \\
\text { deviation }\end{array}$ & Minimum & Maximum \\
\hline \multicolumn{6}{|l|}{ County Data } \\
\hline PCT_CROPINC30 & 2,187 & 0.991 & 0.059 & 0.000 & 1.000 \\
\hline PCT_ACRES_PAST30 & 2,249 & 0.386 & 0.205 & 0.000 & 1.000 \\
\hline VALGR_INC_CROP30 & 2,259 & 0.416 & 0.281 & 0.000 & 0.982 \\
\hline UNEMP30 & 2,252 & 0.044 & 0.031 & 0.000 & 0.271 \\
\hline SMLFM30 & 2,254 & 0.534 & 0.292 & 0.000 & 1.000 \\
\hline$($ DAGLBE) $\times($ PCT_CROPINC30) & 2,187 & -0.223 & 1.009 & -1.534 & 25.805 \\
\hline PCT_STBANK & 2,259 & 0.583 & 0.251 & 0.000 & 1.000 \\
\hline \multicolumn{6}{|l|}{ Quarterly State Data } \\
\hline STBUSFAIL & 565 & -7.006 & 2.551 & -24.488 & -3.640 \\
\hline \multicolumn{6}{|l|}{ Monthly State Data } \\
\hline STBUILDPERM5 & 1,693 & -14.423 & 1.188 & -19.290 & -11.716 \\
\hline STBUILDPERM3 & 1,693 & -13.781 & 1.083 & -15.056 & 26.185 \\
\hline \multicolumn{6}{|l|}{ Monthly National Data } \\
\hline NATDAGP & 39 & 0.003 & 0.036 & -0.070 & 0.078 \\
\hline NATDBUSFAIL & 39 & -0.003 & 0.172 & -0.349 & 0.432 \\
\hline
\end{tabular}

(that is, failures significantly greater than predicted by a stable model of failure determinants for the whole period).

Our model of bank survival posits that the duration of survival (measured in days) depends on fundamentals, which are measured at up to monthly frequency. The survival status of banks after March 1933 is treated as unknown. For each month from January 1930 until March 1933 the future survival paths of banks are regressed on fundamentals to compute the predicted survival hazard function (i.e., the coefficients for the model).

Table 5a reports results for what we term the "basic model," which includes fundamentals and a time trend. The eight columns in Table $5 b$ report coefficient values for eight additional specifications that include variables intended to capture the possible presence of panic, contagion, or illiquidity crises. For the most part, the coefficients on fundamentals in Table $5 \mathrm{~b}$ do not change importantly when the various panic variables are added to the basic specification, and to conserve space we do not report those coefficients. The exceptions are the coefficients on (BONDYLD) $\times($ SEC) and NATDAGP_Lag5M, which do vary across specifications.

We consider four types of variables to capture illiquidity crises, contagion, or panics. First, we include national-level indicator vari- ables for specific panic windows identified by Friedman and Schwartz (1963). Second, we add regional panic indicator variables to capture the regional panics identified by Wicker (1996), and the Chicago 1932 panic. Calomiris and Mason (1997) show that Chicago did indeed suffer a panic in June 1932, but that runs on banks during the panic did not result in the failures of solvent banks. We include the Chicago panic variable not to test for contagion-induced failures there (since our tests are less informative for answering that question than our earlier paper) but rather to gauge the extent to which indicator variables may exaggerate the extent to which panics induced bank failures because of missing location-specific fundamental indicators, as we discuss further below. Third, we include a measure of local contagion (NEARFAILS) to capture the effect of the failure of nearby banks (other banks within the same state that failed in that same month) for predicting a bank's probability of failure.

Fourth, we consider "interaction effects" related to panics. Specifically, we investigate whether measures of bank liquidity or linkages among banks through interbank deposits had special effects on bank failure hazard during episodes identified as panics by prior authors. For example, the ratio of interbank deposits owed to total bank deposits (DTB_TD) may capture a bank's susceptibility to liquidity risk. 
Table 5a-Survival Regressions for Individual Fed Member Banks, Dependent Variable: Log Days Until Failure After December 31, 1929

Full Sample of Fed Member Banks

(Standard Errors in Parentheses)

\begin{tabular}{|c|c|c|c|}
\hline & (1) & & $\begin{array}{c}(1) \\
\text { (Continued) }\end{array}$ \\
\hline Constant & $\begin{array}{c}6.044 \\
(0.283)\end{array}$ & BPR_TD & $\begin{array}{r}-1.490 \\
(0.146)\end{array}$ \\
\hline LTotAss & $\begin{array}{c}0.105 \\
(0.011)\end{array}$ & PrivBPR_BPR & $\begin{array}{r}-0.126 \\
(0.050)\end{array}$ \\
\hline STBANK & $\begin{array}{l}0.136 \\
(0.031)\end{array}$ & INTCOST & $\begin{array}{c}-0.671 \\
(0.428)\end{array}$ \\
\hline LNBRANCH & $\begin{array}{r}-0.012 \\
(0.006)\end{array}$ & PCT_INC_CROP30 & $\begin{array}{c}0.317 \\
(0.093)\end{array}$ \\
\hline MKTPWR & $\begin{array}{c}0.259 \\
(0.099)\end{array}$ & PCT_ACRES_PAST30 & $\begin{array}{c}0.063 \\
(0.063)\end{array}$ \\
\hline NonCash_TotAss & $\begin{array}{c}-0.845 \\
(0.124)\end{array}$ & VALGR_INC_CROP30 & $\begin{array}{r}-0.016 \\
(0.058)\end{array}$ \\
\hline Loans_OtherNonCash & $\begin{array}{r}-0.229 \\
(0.058)\end{array}$ & UNEMP30 & $\begin{array}{c}-1.204 \\
(0.315)\end{array}$ \\
\hline LIQLOANS & $\begin{array}{l}0.115 \\
(0.054)\end{array}$ & SMFARM30 & $\begin{array}{r}-0.075 \\
(0.052)\end{array}$ \\
\hline Losses_Exp & $\begin{array}{c}0.027 \\
(0.049)\end{array}$ & $($ DAGLBE $) \times($ PCT_CROPINC30) & $\begin{array}{c}0.139 \\
(0.036)\end{array}$ \\
\hline REO_NonCash & $\begin{array}{r}-3.415 \\
(0.331)\end{array}$ & PCT_STBANK & $\begin{array}{r}-0.288 \\
(0.047)\end{array}$ \\
\hline$(\mathrm{BONDYLD}) \times(\mathrm{SEC})$ & $\begin{array}{r}-0.247 \\
(0.239)\end{array}$ & STBUILDPERM_Lag5M & $\begin{array}{c}0.054 \\
(0.010)\end{array}$ \\
\hline NW_TA & $\begin{array}{l}1.700 \\
(0.184)\end{array}$ & STBUSFAIL_Lag3Q & $\begin{array}{c}-0.005 \\
(0.004)\end{array}$ \\
\hline$(\mathrm{DD}+\mathrm{DTB}) \_\mathrm{TD}$ & $\begin{array}{r}-0.164 \\
(0.059)\end{array}$ & NATDAGP_Lag5M & $\begin{array}{r}-0.086 \\
(0.264)\end{array}$ \\
\hline DTB_TD & $\begin{array}{r}-0.478 \\
(0.203)\end{array}$ & NATDBUSFAIL_Lag5M & $\begin{array}{r}-0.057 \\
(0.054)\end{array}$ \\
\hline DFB_CashAss & $\begin{array}{c}0.059 \\
(0.060)\end{array}$ & TIME & $\begin{array}{c}0.044 \\
(0.001)\end{array}$ \\
\hline $\begin{array}{l}\text { Number of observations (bank-months) } \\
\text { Log-likelihood }\end{array}$ & $\begin{array}{r}269,683 \\
-11,704\end{array}$ & & \\
\hline
\end{tabular}

Sources and definitions: Definitions of variables are provided in Table 1 and sources are described in the Data Appendix. Indicator variables for individual months appear as DUM, followed by the month and year of the indicator variable. Lags are indicated by appending_Lag, followed by an indication of the lag length $(3 \mathrm{M}=$ three months, $3 \mathrm{Q}=$ three quarters). Time is a monthly time trend.

Evidence of a significant negative coefficient on this variable may suggest that liquidity risk was a significant contributor to failure risk throughout our period. Our test of interaction effects examines whether alleged panic episodes were times of unusual sensitivity to liquidity risk.

The use of panic indicator variables, interaction effects, or nearby failures to test for contagion in producing unwarranted bank failures is a "one-sided" test, by which we mean that it is capable of rejecting, but not proving, the presence of a contagion effect. A statistically significant negative coefficient for any of the four types of panic/contagion indicators implies one of two possibilities: (1) an increased probability of failure that is unrelated to long-run fundamentals (i.e., an unwarranted failure related to temporary illiquidity or contagion), or (2) an incomplete model of fundamentals, where the elements missing in the model matter more for the failures of banks in some times and places than for others. For example, finding a negative residual in our survival model for a particular month may mean that a panic in that month caused failures, or it may mean that our model lacks a fundamental that was important during that month. Finding no significant negative residual or special liquidity interaction effects 
Table 5b-Modified Survival Regressions for Individual Fed Member Banks, Panic Variable Results (Standard Errors in Parentheses)

\begin{tabular}{|c|c|c|c|c|c|c|c|c|}
\hline & (2) & (3) & (4) & (5) & (6) & (7) & (8) & (9) \\
\hline$(\mathrm{BONDYLD}) \times(\mathrm{SEC})$ & $\begin{array}{r}-1.334 \\
(0.280)\end{array}$ & $\begin{array}{c}-0.168 \\
(0.244)\end{array}$ & $\begin{array}{c}-1.072 \\
(0.265)\end{array}$ & $\begin{array}{c}-0.720 \\
(0.202)\end{array}$ & $\begin{array}{c}-0.115 \\
(0.234)\end{array}$ & $\begin{array}{c}-0.338 \\
(0.218)\end{array}$ & $\begin{array}{r}-1.220 \\
(0.290)\end{array}$ & $\begin{array}{r}-2.139 \\
(0.979)\end{array}$ \\
\hline NATDAGP_Lag5M & $\begin{array}{c}0.930 \\
(0.295)\end{array}$ & $\begin{array}{c}-0.181 \\
(0.270)\end{array}$ & $\begin{array}{c}0.806 \\
(0.282)\end{array}$ & $\begin{array}{c}0.794 \\
(0.216)\end{array}$ & $\begin{array}{c}-0.058 \\
(0.259)\end{array}$ & $\begin{array}{c}0.924 \\
(0.234)\end{array}$ & $\begin{array}{c}0.696 \\
(0.304)\end{array}$ & $\begin{array}{c}1.005 \\
(0.999)\end{array}$ \\
\hline FSPANIC-30 & $\begin{array}{c}0.073 \\
(0.035)\end{array}$ & & $\begin{array}{c}0.122 \\
(0.035)\end{array}$ & $\begin{array}{c}0.140 \\
(0.047)\end{array}$ & & $\begin{array}{c}0.101 \\
(0.051)\end{array}$ & & \\
\hline FSPANIC-31a & $\begin{array}{c}0.046 \\
(0.037)\end{array}$ & & $\begin{array}{c}0.050 \\
(0.036)\end{array}$ & $\begin{array}{c}0.106 \\
(0.048)\end{array}$ & & $\begin{array}{c}0.135 \\
(0.052)\end{array}$ & & \\
\hline FSPANIC-31b & $\begin{array}{c}-0.086 \\
(0.029)\end{array}$ & & $\begin{array}{c}-0.043 \\
(0.028)\end{array}$ & $\begin{array}{c}0.066 \\
(0.040)\end{array}$ & & $\begin{array}{c}0.053 \\
(0.043)\end{array}$ & & \\
\hline DUM_JAN33 & $\begin{array}{c}-0.619 \\
(0.063)\end{array}$ & & $\begin{array}{c}-0.570 \\
(0.060)\end{array}$ & $\begin{array}{c}-0.510 \\
(0.045)\end{array}$ & & $\begin{array}{r}-0.478 \\
(0.049)\end{array}$ & $\begin{array}{r}-0.568 \\
(0.067)\end{array}$ & $\begin{array}{r}-0.369 \\
(0.268)\end{array}$ \\
\hline DUM_FEB33 & $\begin{array}{c}-0.452 \\
(0.070)\end{array}$ & & $\begin{array}{r}-0.412 \\
(0.066)\end{array}$ & $\begin{array}{r}-0.415 \\
(0.051)\end{array}$ & & $\begin{array}{r}-0.401 \\
(0.055)\end{array}$ & $\begin{array}{r}-0.411 \\
(0.074)\end{array}$ & $\begin{array}{r}-0.588 \\
(0.226)\end{array}$ \\
\hline DUM_MAR33 & $\begin{array}{c}-0.060 \\
(0.088)\end{array}$ & & $\begin{array}{c}-0.042 \\
(0.084)\end{array}$ & $\begin{array}{c}-0.173 \\
(0.064)\end{array}$ & & $\begin{array}{c}-0.135 \\
(0.070)\end{array}$ & $\begin{array}{c}0.112 \\
(0.093)\end{array}$ & $\begin{array}{c}0.511 \\
(0.497)\end{array}$ \\
\hline$($ FSPANIC-30) $\times($ DFB_CashAss $)$ & & & & $\begin{array}{c}-0.028 \\
(0.151)\end{array}$ & & $\begin{array}{c}0.140 \\
(0.163)\end{array}$ & & \\
\hline$($ FSPANIC-31a) $\times$ (DFB_CashAss $)$ & & & & $\begin{array}{c}-0.049 \\
(0.140)\end{array}$ & & $\begin{array}{c}-0.087 \\
(0.153)\end{array}$ & & \\
\hline$($ FSPANIC-31b) $\times$ (DFB_CashAss $)$ & & & & $\begin{array}{r}-0.277 \\
(0.113)\end{array}$ & & $\begin{array}{c}-0.245 \\
(0.123)\end{array}$ & & \\
\hline WICKER-30 & & $\begin{array}{r}-0.464 \\
(0.085)\end{array}$ & $\begin{array}{c}-0.439 \\
(0.078)\end{array}$ & $\begin{array}{c}-0.419 \\
(0.117)\end{array}$ & & $\begin{array}{c}-0.150 \\
(0.121)\end{array}$ & $\begin{array}{c}-0.327 \\
(0.082)\end{array}$ & $\begin{array}{r}-0.625 \\
(0.326)\end{array}$ \\
\hline WICKER-31a & & $\begin{array}{c}0.055 \\
(0.084)\end{array}$ & $\begin{array}{c}0.047 \\
(0.074)\end{array}$ & $\begin{array}{c}0.215 \\
(0.123)\end{array}$ & & $\begin{array}{c}0.193 \\
(0.133)\end{array}$ & & \\
\hline WICKER-31b & & $\begin{array}{c}-0.307 \\
(0.073)\end{array}$ & $\begin{array}{c}-0.190 \\
(0.065)\end{array}$ & $\begin{array}{c}-0.136 \\
(0.121)\end{array}$ & & $\begin{array}{c}-0.093 \\
(0.132)\end{array}$ & $\begin{array}{r}-0.230 \\
(0.070)\end{array}$ & $\begin{array}{r}-0.034 \\
(0.255)\end{array}$ \\
\hline$($ WICKER-30) $\times$ (DFB_CashAss) & & & & $\begin{array}{c}0.298 \\
(0.301)\end{array}$ & & $\begin{array}{c}-0.429 \\
(0.326)\end{array}$ & & \\
\hline$($ WICKER-31a) $\times$ (DFB_CashAss $)$ & & & & $\begin{array}{r}-0.677 \\
(0.451)\end{array}$ & & $\begin{array}{c}-0.514 \\
(0.487)\end{array}$ & & \\
\hline (WICKER-31b) $\times$ (DFB_CashAss) & & & & $\begin{array}{c}-0.126 \\
(0.433)\end{array}$ & & $\begin{array}{c}-0.236 \\
(0.474)\end{array}$ & & \\
\hline Chicago-6-32 & & & & & $\begin{array}{c}-1.378 \\
(0.727)\end{array}$ & $\begin{array}{r}-1.078 \\
(0.504)\end{array}$ & $\begin{array}{c}-1.259 \\
(0.601)\end{array}$ & $\begin{array}{r}-0.430 \\
(0.353)\end{array}$ \\
\hline NEARFAILS & & & & & & $\begin{array}{c}-0.004 \\
(0.001)\end{array}$ & $\begin{array}{r}-0.006 \\
(0.001)\end{array}$ & $\begin{array}{r}-0.009 \\
(0.002)\end{array}$ \\
\hline Number or observations ( & 269,683 & 269,683 & 269,683 & 269,683 & 269,683 & 269,683 & 269,683 & 53,032 \\
\hline Log-likelihood & $-11,644$ & $-11,681$ & $-11,628$ & $-11,643$ & $-11,679$ & $-11,569$ & $-11,568$ & $-2,076$ \\
\hline
\end{tabular}

Sources and definitions: All models utilize the control variable specification in Table 5a. The results for the control variables do not qualitatively differ from those reported in Table 5a in the presence of the panic variables. Definitions of variables are provided in Table 1 and sources are described in the Data Appendix. Indicator variables for individual months appear as DUM, followed by the month and year of the indicator variable. Lags are indicated by appending_Lag, followed by an indication of the lag length $(3 \mathrm{M}=$ three months, $3 \mathrm{Q}=$ three quarters $)$.

during a Friedman-Schwartz panic window, however, provides evidence against the view that contagion or illiquidity produced bank failures in that month that cannot be explained by fundamentals.

Similarly, regional indicators and interaction effects, and the NEARFAILS variable, provide one-sided tests of local or regional contagion; the absence of statistically significant negative coefficients indicates no residual failures associated with particular regions, or occurring in the neighborhood of other failed banks, but the significance of these effects may simply indicate the absence of regressors that capture important local or regional fundamentals. The potential for making false inferences from these indicators warrants emphasis, especially in light of the fact that all of these indicators were 
constructed based on ex post observations of bank failures. If our fundamental model is incomplete (as it surely is), then indicator variables and interaction effects for specific dates constructed from ex post observations of failures could prove significant even in the absence of true contagion or illiquidity crises.

It is also important to note that indicator variables are uninformative about the particular mechanism through which illiquidity or contagion produces bank failure. Significant unexplained residuals for particular times and places may indicate failures caused by an external drain (as in a flight from the dollar) that produces exogenous withdrawal pressure on banks. Some historians have argued that such a mechanism may have been important in the fall of 1931 and in early 1933. Alternatively, unexplained residual effects may indicate "panic" in reaction to a "contagion of fear" about bank solvency (that is, a massive loss of confidence in the domestic banking system). While we will sometimes refer to the indicator variables as "panic" or "contagion" indicators, for convenience, it is important to bear in mind thatparticularly in the case of the nationwide indicator variables for the fall of 1931 and early 1933 - our measures of possible panic/contagion/illiquidity do not distinguish possible effects of a loss of confidence in domestic banks from a crisis produced by a run on the currency.

\section{A. Indicators of Bank Failure Risk}

Before reviewing the results in Table 5, we first explain the logic underlying the fundamental predictors of survival (see also Calomiris and Mason, 1997). According to basic finance theory, the probability of insolvency should be an increasing function of two basic bank characteristics: asset risk and leverage. Liquidity of assets relative to liabilities may be an additional factor influencing the risk of failure.

Our measures of fundamental bank attributes capture variation in bank asset risk, leverage, and liquidity. Banks that are larger (higher LTotAss) are better able to diversify their loan portfolios, reducing their asset risk. Thus, ceteris paribus, large banks should have lower failure risk (higher survival hazard). Banks that achieve their size through a branching network (LNBRANCH) should also be more diversified, ceteris paribus. There is substantial evidence for the stabilizing effects of branching in U.S. banking history (Calomiris, 2000). Nevertheless, as contemporaries during the Depression and Calomiris and David C. Wheelock (1995) note, some of the largest branching networks in the United States collapsed during the 1930's, indicating that the 1930's may have been something of an exception from the standpoint of the stability of branching banks. Many large branching banks were active acquirers during the 1920's, taking advantage of windows of opportunity provided by the distress of unit banks. Many of those acquirers, therefore, were in a vulnerable position (i.e., they had just acquired a relatively weak portfolio of assets) at the beginning of the 1930's. Furthermore, Mark Carlson (2001) argues that branching made banks more vulnerable to the aggregate shocks of the Great Depression. Branching provides diversification of sectoral risks, and thus permits branching banks to take on more loan risk. But branching does not offer as much protection during an economywide Depression (like that of the 1930's) that affects all sectors. Because branching banks believed that they were more protected against loan loss than other banks, they took on more loan risk and were subject to a greater shock when Depression-era loan losses occurred.

State-chartered banks operate under different regulations, and in general were given greater latitude in lending. Thus, it may be that national banks were constrained to have lower asset risk than state banks.

Measures of the proportions of different categories of assets (NonCash_TotAss, Loans_ OtherNonCash, LIQLOANS, and DFB_CashAss) capture the degree of ex ante asset risk, and the liquidity of assets. Loan losses (Losses_Exp) and real estate owned (REO_NonCashAss) are ex post measures of asset quality.

Bank net worth relative to assets (NW_TA) measures the extent of leverage using book values. Book values are imperfect measures of net worth, but market values are not available for most of the banks in our sample. The structure of bank liabilities (captured here by various ratios of components of deposits relative to total deposits) also provides information about bank failure. Calomiris and Mason (1997), among others, have found that weak banks were forced to expand their reliance on high-cost categories of debt (that is, debt held by relatively informed 
parties), and that the ratio of bills payable to total deposits (BPR_TD) is a useful indicator of fundamental weakness. It may also be that a reliance on demandable debt (DD + DTB) increased bank liquidity risk, and thereby contributed to failure. The average interest rate paid on deposits (INTCOST) is a direct measure of bank default risk, but a lagging measure (dependent on the frequency of deposit rollover).

The bank market power variable is included to capture the potential role of "rents" related to a bank's market power for boosting the market value of bank net worth, and therefore, reducing the effective leverage ratio of the bank. Carlos D. Ramirez (2000) found this variable was useful in predicting failures of banks in Virginia and West Virginia in the late 1920's.

We also include a measure of the exposure of the bank's securities portfolio to changes in bond yields $($ BONDYLD $\times$ SEC), to capture what we call the "Temin effect." Temin (1976, p. 84) writes that: "The principal reason usually given for [post-1930] bank failures is the decline in the capital value of bank portfolios coming from the decline in the market value of securities." Wicker (1996, p. 100) disputes that view, and argues instead that bank loan quality was the dominant source of fundamental shock that led to bank failures. Our model includes measures of loan quantity and quality, but we also include BONDYLD $\times$ SEC to capture bank vulnerability to changes in bond yields.

Some county-level characteristics take account of the shares of various elements of the agricultural sector in the county economy, and the extent to which agricultural investment grew during the 1920's. That emphasis reflects the view of White (1984), Wicker (1996), and others that much of the distress suffered by banks during the 1930's was a continuation of the distress suffered in agricultural areas during the 1920's. Other county-level, state-level, and national-level variables (including unemployment, building permits, business failures, and agricultural prices) capture general economic conditions in the county, state, and country. ${ }^{4}$

\footnotetext{
${ }^{4}$ One potential concern is reverse causation-that is, the possibility that business failures or building permits are endogenous to shocks originating in the banking sector. For example, it is possible that panics produce declines in building and increases in business failures, which in turn predict future bank distress (either because of serial correlation in
}

\section{B. Regression Results for the Bank Survival Model}

The results for the basic model in Table 5a show that many fundamentals have explanatory power for bank survival (failure). Generally, coefficients are of the predicted sign and highly significant. Bank size (LTotAss) is positively associated with survival. Higher net worth is also associated with longer survival. A reliance on demandable debt rather than time deposits, where the demandable debt ratio is the sum of demand deposits held by the public and interbank deposits relative to total deposits [(DD + DTB)_TD], lowers survival probability. But interbank deposits have a much larger effect than demand deposits of the public. The interbank deposits effect is given by the sum of the coefficients on (DD + DTB)_TD and on DTB_TD (that is, the sum of -0.164 and $-0.478)$. The effect of interbank deposits may reflect either liquidity risk or the fact that weak banks were forced to rely more on interbank credit, and our results are not able to distinguish between these two interpretations. Consistent with the latter interpretation, nondemandable debt from informed creditors (bills payable or rediscounts), however, has the largest effect on survival probability of any debt category. Bills payable or rediscounts from official sources enters with a coefficient of -1.490 , while such debt from private sources has a somewhat larger effect (the sum of the two coefficients, -1.490 and -0.126$)$.

State-chartered banks (STBANK) were less likely to fail, ceteris paribus, than national banks. This is a somewhat surprising result for which we lack a clear interpretation. Nevertheless, we are able to say that constraints on the lending of national banks likely were not very important for limiting their relative risk. Our interpretation of the state-chartered indicator

bank distress, or because of fundamental links from economic activity to banking distress). That problem is mitigated, but not eliminated, by our use of lagged values of high-frequency fundamentals. Calomiris and Mason (2003a, 2003b) address the question of the dynamic relationship among bank failures, business failures, and building permits at the state level. We find little effect of autonomous shocks to bank failures on other variables, and little serial correlation in the bank failure process. Thus, those results support the assumed exogeneity of fundamental determinants of bank failure. 
variable is not complicated by possible selectivity bias related to a bank's choice of location (i.e., that state banks were more present in certain counties) because we include a separate variable (PCT_STBANK) to capture the propensity of banks in a given county to be statechartered, and therefore, we control for location-specific selectivity bias. That control variable has a negative sign, indicating that counties with a greater proportion of statechartered banks suffered higher bank failure rates, ceteris paribus.

Branching (LNBRANCH) is negatively related to survival duration, after controlling for other effects (including size). This result may reflect the unusual vulnerability of branching banks in the early 1930's. In future work, we plan to investigate the extent to which prior acquisitions of distressed banks by branching banks may explain this result.

Consistent with Ramirez's (2000) findings for Virginia and West Virginia in the late 1920 's, greater market power (MKTPWR) lowers failure risk.

Consistent with Wicker's (1996) emphasis on loan quality as a source of fundamental problems, more lending and lower bank asset quality (measured either ex ante by NonCash_TotAss, Loans_OtherNonCash, and LIQLOANS or ex post by REO_NonCashAss) is associated with lower survival. We found no differences in failure risk associated with the composition of cash assets (which we define as the sum of cash, reserves at the Fed, government securities, and deposits due from banks). We report the results for the ratio of due from banks relative to total cash assets (DFB_CashAss), where the coefficient measures the effect of increasing the relative share of due from banks in total cash assets. It has an insignificant positive effect on survival duration.

Higher debt interest cost is associated with lower survival rates, but this is not a significant or robust result. The insignificance of higher debt interest cost reflects the correlation between interest cost and other regressors that capture asset risk, leverage, and debt composition. In the absence of those other variables, it is a significant predictor of failure risk.

Banks with relatively high securities portfolios suffered greater risk of failure when bond yields rose, as predicted by Temin (1976), but the effect is not significant in the basic model.
Note, however, that the size of the coefficient on $($ BONDYLD) $\times($ SEC) is larger and often significant in other regressions in Table 5, specifically in regressions that include indicator variables for the first three months of 1933 [that is, regressions other than (1), (3), and (6)]. This result has an intuitive interpretation; when one controls for the most important episode of nationwide panic or illiquidity crisis (during which a flight to quality would have raised the price of government securities, but not other securities held by banks), the Temin effect on the average securities portfolio should be stronger.

Thus our results on the effects of bank portfolio composition on failure risk indicate that, in a sense, both Temin and Wicker were correct: banks with more lending, and riskier lending, were more vulnerable than other banks, ceteris paribus, but to the extent banks had securities portfolios, rising bond yields increased their failure risk.

Some county characteristics are highly significant. Higher unemployment (UNEMP30) lowered bank survival rates. More agriculture, per se, does not appear to have been a problem. In fact, a reliance on agriculture as a source of income was associated with increased survival rates. But the relative health of the agricultural sector made a difference for bank survival. In counties where agriculture was an important and healthy sector, as indicated by the interaction of the percent of income earned from crops and the investment in agricultural capital during the 1920's [(DAGLBE) $\times\left(\mathrm{PCT}_{-}\right.$ CROPINC30)], bank survival rates were higher. The extent that a county's agricultural income was based in grains (VALGR_INC_CROP30), as opposed to pasture (PCT_ACRES_PAST30), did not enter significantly. A greater presence of small farms in a county (SMFARM30) had a negative, but not a highly significant or robust, effect on bank survival.

At the state level, the effect of lagged monthly building permits (STBUILDPERM_ lag5) on bank survival proves positive and highly significant, while lagged quarterly liabilities of business failures does not prove significant. At the national level, monthly liabilities of business failures has a negative sign but is not highly significant. Monthly agricultural price change is insignificant in the basic model, but becomes significant when panic indicator 
variables are added [in regressions (2), (4), (5), (7), and (8)].

Regression (2) in Table 5b shows the result of including indicator variables for FriedmanSchwartz national banking crises alongside our other variables. Owing to the complexity of the suspension and failure process in early 1933 , the 1933 crisis indicators are divided into three separate monthly indicator variables for January, February, and March. Regression (3) of Table $5 b$ includes indicator variables for the three regional panics identified by Wicker. Regression (4) of Table $5 b$ includes both the Friedman-Schwartz and the Wicker crisis indicator variables. Regression (5) adds interactive effects related to due from banks to the specification of regression (4). Regression (6) adds the June 1932 Chicago panic indicator alone to our basic model. Regression (7) adds the Chicago panic indicator and the NEARFAILS variable to the regression (5) specification. Regression (8) drops many of the insignificant regressors from regression (7). Regression (9) is the same as regression (8), but includes only banks in the principal 215 cities in the United States, which permits a comparison of the determinants of failure in rural and urban areas.

In regression (2), and in all other specifications, we find that the indicator variables for two of the four Friedman-Schwartz panics (those of late 1930 and mid-1931) are positive and, in one case, significant. That is, contrary to Friedman and Schwartz, those episodes were times of unusually high bank survival, after controlling for fundamentals, not episodes of inexplicably high bank failure. We do not view this result as indicative of "irrational exhuberance" on the part of depositors during those episodes, but rather of an incomplete model of fundamentals. The indicator variable for the September-November 1931 period is significant and negative in regression (2), as are the indicator variables for January and February 1933. The indicator for March 1933 is insignificant. If we had assigned all bank failures for April-December 1933 to March 1933 (which we argue, on balance, against doing above) the only qualitative difference in our results is the indicator variable for March 1933, which becomes much larger in absolute value and significant. Thus, unsurprisingly, one cannot reject the possibility that March bank failures resulted from contagion if one includes many banks that failed after March in the definition of March failures.

The results in regressions (3) and (4) support (but do not prove) Wicker's view that sudden waves of bank failure unrelated to observable fundamentals (prior to 1933) were largely regional affairs. Two of Wicker's regional indicators prove negative and significant (for late 1930 and for September-October 1931). An indicator for the third regional panic identified by Wicker (that is, mid-1931) enters with the wrong sign and is not significant. In regression (4), in the presence of the Wicker regional indicator for the fall of 1931, the Friedman and Schwartz national indicator for that episode declines in magnitude and becomes statistically insignificant.

Conclusions based on the magnitude and significance of indicator variables for panics could conceivably provide a misleading picture of the effects of panic episodes on the bank failure process. For example, even if panics are episodes in which liquidity matters a great deal for the incidence of bank failure, and in which indicators of fundamental solvency do not matter as much as during nonpanic episodes, panic indicator variables might not prove negative and significant in a regression that assumes regression coefficients are constant.

Thus, it is conceivable that our conclusions about the first three Friedman-Schwartz episodes could change if we took account of changes in regression coefficients during those episodes. To investigate that possibility, we relaxed the assumption that the coefficients on our fundamentals were constant, and allowed them to vary over time. Specifically, we allowed coefficients to change during the first three episodes identified by Friedman and Schwartz as panics. Our results did not support the view that indicators of liquidity mattered more during panics, or that indicators of fundamental insolvency mattered less during panics. Indeed, our failure risk model was remarkably stable. In the first Friedman-Schwartz episode (late 1930), three variables out of 28 showed somewhat significant changes in coefficients during the episode: the state bank indicator (a 0.0159 significance level), the ratio of private bills payable and rediscounts to total bills payable and rediscounts (a 0.0479 significance level), and interest cost (a 0.0263 significance level). In the second Friedman-Schwartz episode, no coefficient 
changes were significant. In the third episode, due from banks as a fraction of cash assets was significant (at the 0.0033 significance level).

Three facts are salient. First, randomly one should expect that three out of 84 regressors would be significant at the 0.0357 level (that is, $1 / 28$ ), and we found that only three variables were significant at that level. Second, different interaction variables were significant across episodes. Third, only one of the coefficients is possibly interpretable as a special panic liquidity effect-the negative effect for the interaction of the third episode with the due from banks variable, (FSPANIC-31b) $\times$ (DFB_CashAss). In other words, in the fall of 1931, banks that relied on deposits in other banks as a source of cash assets found that those assets were not perfect substitutes for other cash assets (cash, reserves at the Fed, and government securities).

To further investigate the role of the due from banks variable during alleged panics, in regressions (5) and (7) of Table 5b we include interaction effects that allow the coefficient on DFB_CashAss to vary during all the episodes identified by Friedman and Schwartz or by Wicker as panics. As Table 5b shows, this effect is only significant for (FSPANIC-31b) $\times\left(\mathrm{DFB}_{-}\right.$ CashAss). Including that variable, however, changes the sign of the FSPANIC-31b indicator variable to positive, and reduces the overall combined effect of the two variables (when evaluated at the mean of DFB_CashAss). Overall, we concluded that our survival model is quite stable over time and that there is little gained from allowing coefficients to change during episodes of alleged panic. ${ }^{5}$

In results not reported here, we also experimented with disaggregation of the DFB CashAss variable (which our data allow us to divide among accounts held in Chicago, New York, or other cities). We found that accounts held in Chicago entered negatively relative to those of other cities, but this result disappears in the presence of the indicator variable for the June 1932 Chicago banking panic. In other words, the illiquidity of money held in Chicago banks was mainly relevant only for the failure

\footnotetext{
${ }^{5}$ We also experimented with varying regression coefficients during January and February 1933 . One of 28 regressors_-total bills payable and rediscounts (BPR_TD)—was somewhat significant (with a 0.051 significance level).
}

risk of Chicago banks, and only in one month of the sample.

With respect to local contagion, the NEARFAILS variable is significant in all survival regressions that include it, even when the Friedman-Schwartz and Wicker indicator variables are also included. The June 1932 indicator for Chicago is significant even when we include the NEARFAILS variable in the regression. Since Calomiris and Mason (1997) provide evidence against viewing bank failures in Chicago in June 1932 as the result of contagion, we view that finding as illustrative of the danger of interpreting indicator variables as proof of contagion (rather than as evidence of missing fundamentals).

In regression (9), we investigate differences between city banks and rural banks. All variables are defined similarly to those of the previous regressions with one exception; building permits are defined at the level of the city in which the bank is located, rather than aggregated to the state level. Results are similar to those of regression (8), apart from differences in significance that may be attributable to the relatively small sample size of city banks (which comprise roughly one-fifth of our nationwide sample). The main differences between regressions (8) and (9) are as follows. Deposits held by banks (DTB_TD) has a smaller and insignificant sign in the city bank failure regression. This result suggests that deposits held by rural banks in city banks were not a source of special illiquidity risk during the Great Depression. Other differences include the insignificance of county unemployment for city banks, the smaller and less significant coefficients for the Wicker-31b indicator and the indicator for the Chicago panic of June 1932. Perhaps not surprisingly, the latter effect indicates that in comparison to other cities, and using a model derived solely from the experience of city banks, there is less of an unexplained residual for Chicago bank failures in June 1932.

In summary, our results provide evidence against the Friedman-Schwartz view that the bank failures of late 1930 and 1931 were autonomous shocks produced by nationwide contagion or panic. Our results are consistent with (but do not prove) Wicker's (1996) view that regional rather than national contagion characterized the crises of late 1930 and late 1931, and they are consistent with (but do not prove) 


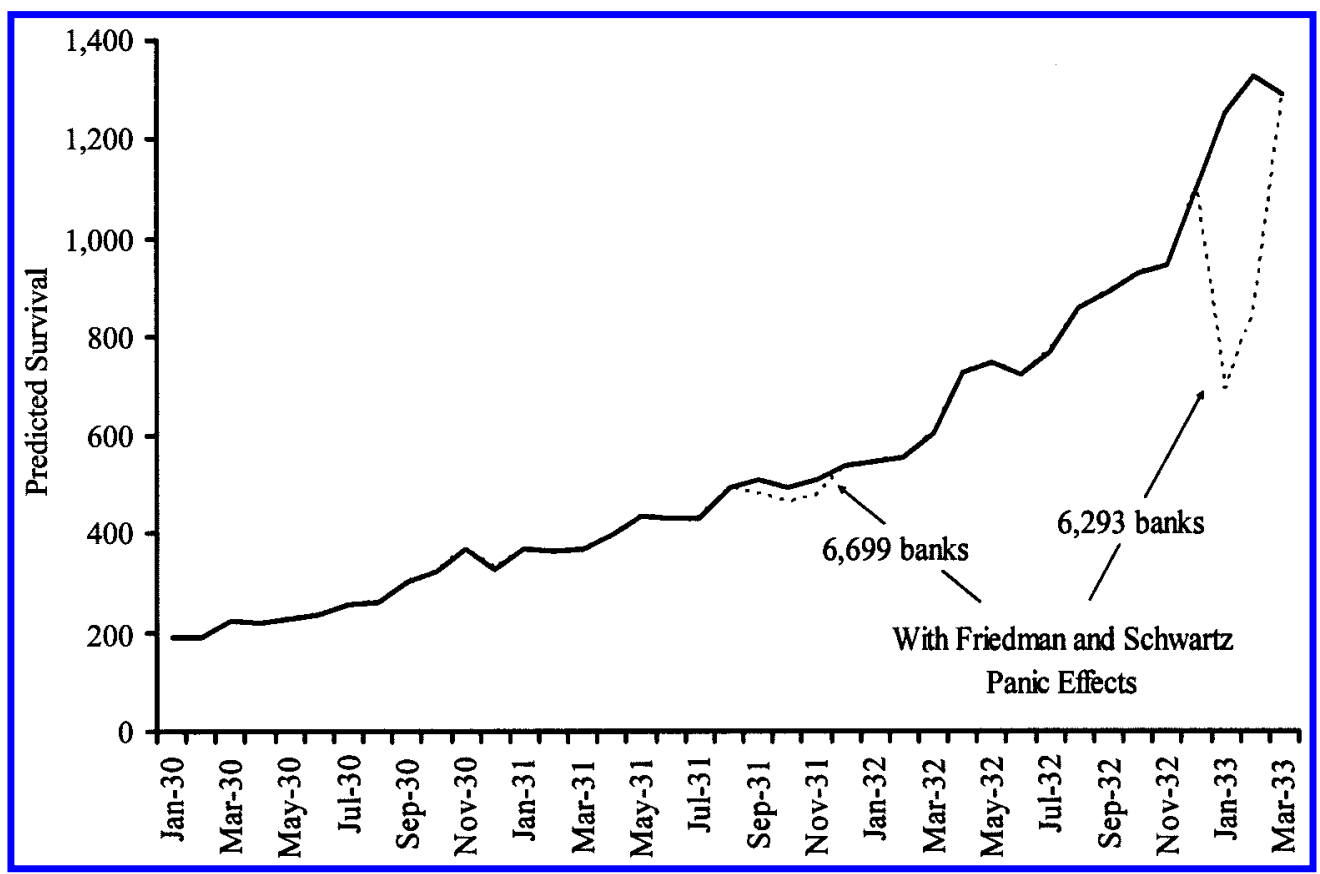

Figure 4. Predicted Survival During Friedman and Schwartz "Panic" Episodes

Friedman and Schwartz's and Wicker's view that bank failures in January-February 1933 resulted in part from nationwide panic. Our finding that local bank failures raise the probability that another local bank will fail is also consistent either with omitted local fundamentals or local bank contagion.

\section{Placing an Upper Bound on the Importance of "Panic" Effects}

Are the effects of panics (national, regional, or local) potentially large economically as well as significant statistically for the United States as a whole? Thus far, we have argued that some indicators of local, regional, or national panic cannot be rejected. That is, some bank failures are not fully explained by a stable model of the bank failure process for the period 1930-1933. Late 1930 and late 1931 may have been episodes of regional panic. January and February 1933 may have been a time of nationwide panic. Local contagion effects may have been present throughout the sample period. As we have repeatedly noted, all of our tests of panic or contagion effects are "one-sided" and likely overestimate the true incidence of panic, since relevant fundamentals are likely omitted from our model.

Nevertheless, our estimates of local, regional, and national panic effects can be used to place an upper bound on the importance of estimated panic effects for the United States as a whole. Figures 4-7 plot the mean estimated survival duration (in days) for banks in our sample over time, using different estimation equations, with and without taking account of panic indicator variables. All the figures display a rising trend, which reflects the rising average conditional survival probability of banks over our time period.

Figure 4 corresponds to regression (2) of Table $5 b$, in which only the basic model cum Friedman-Schwartz indicator variables is used for the estimation. The dashed line in Figure 4 is the mean survival estimate using all the basic regression coefficients, and the FriedmanSchwartz indicators for the late-1931 period and the early-1933 period (the indicators for late 1930 and mid-1931 are set at zero). The solid line in Figure 4 shows the average estimated survival duration if all the Friedman-Schwartz indicator variables are set at zero. Figure 4 shows that even if one wanted to argue that 


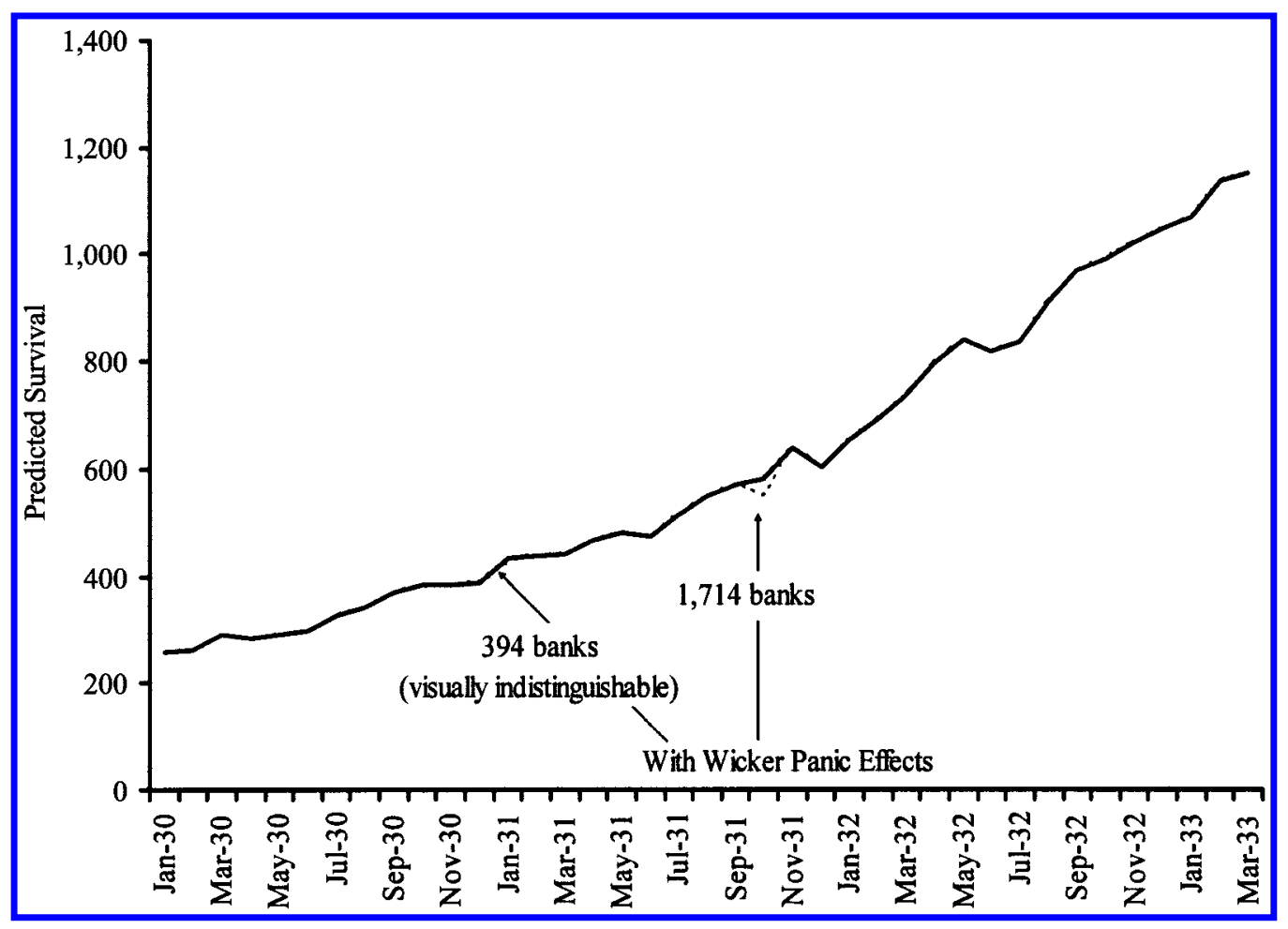

Figure 5. Predicted Survival During Wicker "Panic" Episodes

the late-1931 episode was a nationwide panic (contrary to the evidence presented above), it is still not an important episode of unexplained bank failure. In contrast, including indicators for January and February 1933 substantially reduces the predicted average survival duration in those months. We conclude that our upper bound estimate of the effects of national panic indicate potentially important effects from panics only in early 1933.

Figure 5 corresponds to regression (3) of Table 5b. As in Figure 4, the dashed line is the prediction of the basic model plus the first and third Wicker indicator variables (as before, the indicator variable with the "wrong sign" is set at zero). The solid line shows the effect of omitting the Wicker indicators for the two episodes. Note that these effects, while substantial for the banks in the affected regions, are confined to those regions, and thus are not large for the nation as a whole. In the case of the 1930 regional episode, only 394 banks are in the regions affected by the indicator variable; in the case of the late 1930 regional episode, 1,714 banks are in affected regions.

Figure 6 corresponds to regression (6) of Table $5 \mathrm{~b}$. The dashed line of the figure includes the effects of all coefficients, while the solid line excludes the June 1932 Chicago indicator variable. The estimated effect on survival duration, while large for affected banks, is trivial for the country as a whole because only 29 Chicago banks are affected.

The NEARFAILS variable can be used to put an upper bound on the potential importance of location-specific contagion effects. In a survival regression that includes the basic model and NEARFAILS, the omission of NEARFAILS from the estimation of survival duration raises the average estimated survival duration of banks for each month in our sample period by an average of 0.2 percent. Figure 7 shows the effect of omitting this effect from the survival model.

We conclude that prior to January 1933, the effects of panics - whether national, regional, 


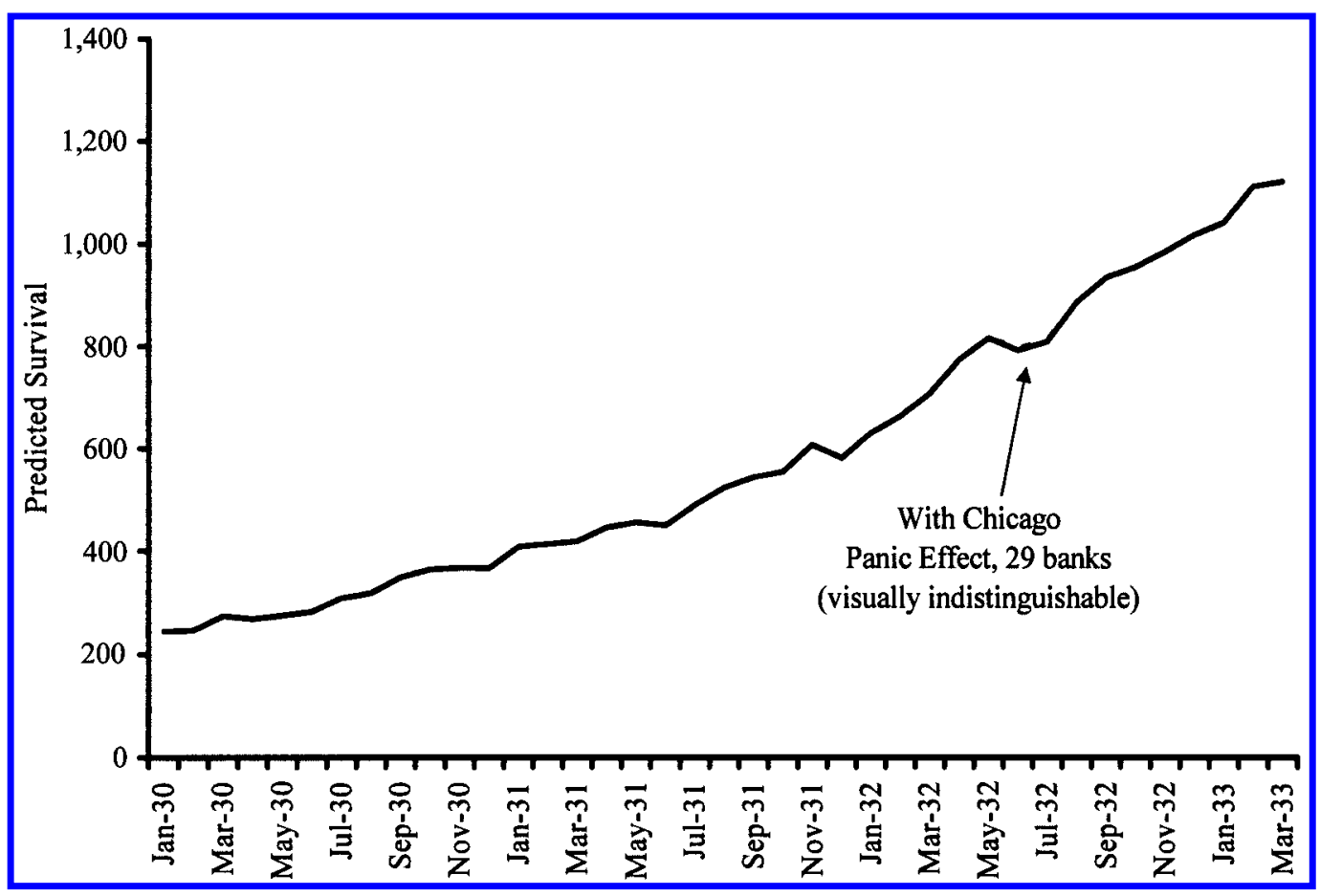

Figure 6. Predicted Survival During Chicago "Panic" Episode

or local-contributed little to the failure risk of Fed member banks in the nation as a whole. A stable model of bank fundamentals can account for the bulk of regional and temporal variation in bank failure risk during the period 19301933.

Our conclusion that panic effects were not potentially important until January 1933 has three important implications for the literature on bank failures during the Great Depression. First, it implies a limited role for nonfundamental causes of bank failures during the Depression. January 1933 was quite late in the history of the Depression (which reached its trough in March 1933). Second, it implies that bank failures during the crucial period of 1930-1932, which saw substantial declines in bank assets and deposits, were not an autonomous shock, but rather an endogenous reflection of bank condition and economic circumstances. Third, the special circumstances of early 1933 - the origins of which Wigmore (1987) traces to a run on the dollar rather than a loss of confidence in the solvency of the banking system-suggest that the only nationwide episode that saw the sudden burst in bank failures unrelated to measures of fundamentals may have had little to do initially with a "contagion of fear" about banks and more to do with expectations of Roosevelt's departure from gold, which in the event, were accurate. In other words, one could argue that the missing "fundamental" in the failure risk model was the probability of the government's departure from gold. That interpretation of the events of 1933 would suggest even less room for "contagions of fear" about bank condition as a contributing influence to bank failure during the Depression.

\section{Conclusion}

We are able to identify close links between fundamentals and the likelihood of individual bank failure from 1930 through 1933. Fundamentals include both the attributes of individual banks, and the exogenous local, regional, and national economic shocks that affected their health. We also develop a set of tests for the presence of liquidity crises or contagion. In addition to regressors that capture fundamental determinants of bank distress, we include 


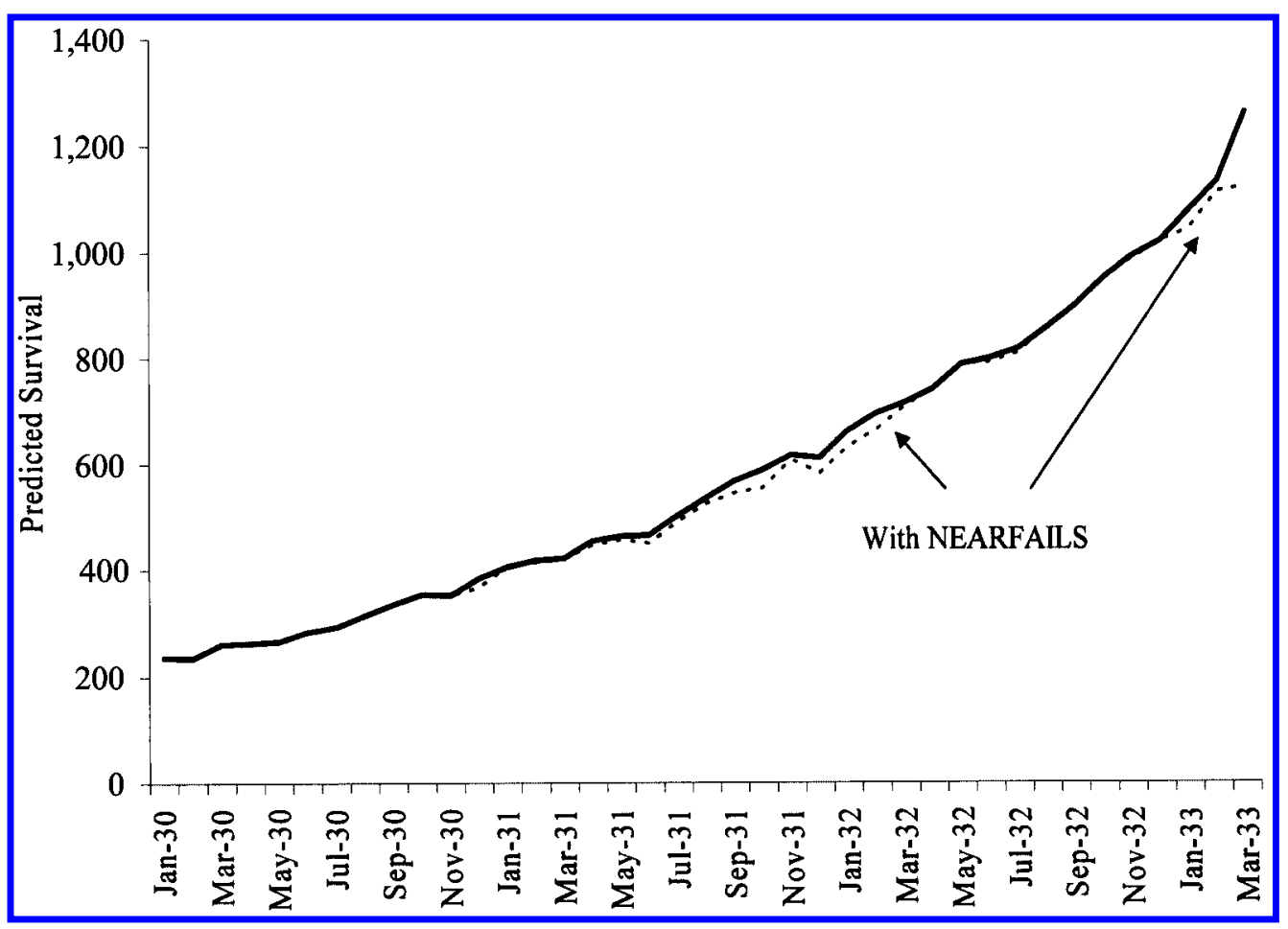

Figure 7. Predicted Survival with Other Deposits in Failed Banks in the County

indicator variables to capture residual effects of alleged national and regional panic episodes identified by Friedman and Schwartz (1963) and Wicker (1996). This approach is capable of rejecting, but not convincingly confirming, the incidence of panics. We find no evidence that bank failures were induced by a national banking panic in the first three episodes Friedman and Schwartz identify as panics (late 1930, mid1931, and late 1931). We do find, however, that in January and February 1933 there is a significant increase in bank failure hazard that is not explained by our model of fundamentals.

Indicator variables for the states and periods identified by Wicker as suffering regional crises in 1930 and 1931 indicate significant regionspecific increases in the probability of bank failure that are not explained by our model of fundamentals in two of the three cases identified by Wicker (late 1930 and late 1931). At the local level, we find that the failure of nearby banks (NEARFAILS) is associated with an increase in the probability of bank failure.

When we find evidence consistent with the presence of panics our results have two possible interpretations: either that illiquidity crises occurred and resulted in some unwarranted bank failures (as Friedman and Schwartz and Wicker have argued) or that our model of the fundamental causes of bank failures is incomplete. The results of our earlier study of the Chicago banking panic of June 1932 (Calomiris and Mason, 1997) indicated that banks in Chicago in June 1932 did not fail due to an illiquidity crisis or panic, but rather as the result of fundamental shocks that were local and sudden. That example leads us to believe that it is quite possible that the significance of the January-February 1933 panic indicators, the NEARFAILS variable, and two of the Wicker panic indicators result at least in part from a failure to fully model changes in relevant economic conditions. In future work, we intend to take a closer look at bank failures during the regional crises of 1930 and 1931, and at the January-February 1933 nationwide experience, to investigate that possibility.

Our results indicate a much smaller role for 
contagion and liquidity crises in explaining the bank failures of 1930-1932 (and the contraction of the money stock that accompanied them) than that envisioned by Friedman and Schwartz (1963). The regional panics identified by Wicker may have been important local or regional events, but they had small and temporary effects on average bank failure hazard in the aggregate. And the effect of location-specific contagion seems to have been similarly small in its importance. To the extent that nationwide panic may explain bank failures, its role is relatively late in the sequence of events of the Depression and brief (lasting a matter of weeks in early 1933), and involved a small proportion of the bank failures during the period 19301933. Our findings suggest that disaggregated analysis of bank failures and deposit shrinkage leads to a much smaller role for contagion in understanding bank distress during the Great Depression.

Nevertheless, three caveats warrant mention. First, our sample consists of Fed member banks. It may be that nonmember banks had a different susceptibility to panics. Second, we use failure rather than suspension as our measure of bank distress. We are unaware of any records of individual bank suspension dates, and also consider failure a more meaningful indicator of distress (following the reasoning of Ali Anari et al., 2002), but we recognize that suspensions that did not result in failure may also have been disruptive, and that we are not able to capture those effects in our analysis. Third, there are other potential mechanisms for the transmission of contagion that we have not been able to investigate. For example, ownership linkages among chain banks may have been important in promoting runs on the solvent affiliates of failed banks. It remains to be seen how ownership linkages, or perhaps correspondent linkages, may have mattered for the transmission of failure among banks during the Depression.

With respect to the policy implications of our findings, it is important to distinguish macroeconomic and microeconomic policies. There can be little doubt that expansionary open market operations in 1930 and 1931 (or departure from the gold standard in 1931, when many other countries did so) could have avoided macroeconomic collapse in 1931-1933, and therefore, would have substantially mitigated bank distress. Without a different macroeconomic policy, given the importance of fundamental sources of bank failure, it is doubtful whether the Federal Reserve System, state governments, or the national government could have done much in the way of traditional microeconomic liquidity assistance (either through collateralized lending or temporary suspension of convertibility) to rescue failing banks during 1930-1932. Only a combination of expansionary monetary policy and bank bailouts (e.g., in the form of subsidized bank recapitalization, as was effected by the Reconstruction Finance Corporation after the banking crisis of 1933) could have prevented banks from failing in 1930-1932 (see Mason, 2001a).

Policy options in 1933 are more ambiguous. The fact that the only nationwide episode during which panic indicators are significant (early 1933) coincided with substantial external drain (the alleged run on the dollar in early 1933) suggests that liquidity assistance targeted to individual banks might have been helpful in January 1933, particularly if it had been combined with expansionary monetary policy and an immediate departure from the gold standard. ${ }^{6}$

\section{Data ApPendix}

Our data set contains a wide variety of variables that differ by frequency, geographic scope, and level of disaggregation. In this Appendix we describe briefly the definitions and sources for our data, and explain the limits of our sample.

The data used in our analysis can be broken down into six major types: individual bank characteristic data; county-level bank characteristic data; county economic data; state economic data; national economic data; and other data constructed to measure systemic bank distress. Following are the sources and details underlying each type of data.

\section{Individual Bank Characteristics}

With the help and support of the St. Louis Fed and the University of Illinois, Urbana-Champaign,

\footnotetext{
${ }^{6}$ If Wigmore is right about the run on the dollar in early 1933, one could argue that lender of last resort assistance and expansionary monetary policy in early 1933 would have been ineffectual in stemming the outflow from the banks without an immediate departure from gold.
} 
and subsequently, with funding from the $\mathrm{Na}-$ tional Science Foundation, we assembled banklevel balance sheet and income statement data from microfilm records of "call reports" of Federal Reserve member banks (see Mason, 1998, for an overview of the call report data we collected). Individual bank data come from original manuscript Reports of Condition (forms Federal Reserve 105 and Treasury 2129) and Reports of Earnings and Dividends (forms Federal Reserve 107 and Treasury 2130) filed by Federal Reserve member banks. In 1946, the Federal Reserve Board began microfilming original manuscript call reports for selected dates back to 1914. The Board authorized the destruction of extant manuscript Reports of Condition and Reports of Earnings and Dividends after microfilming. Though summary individual bank balance sheet data were sometimes published in annual reports of the Federal and state bank supervisory authorities, the microfilm record available at the Board is the only known record of original manuscript Reports of Condition that remain from the early twentieth century, and this record contains far more detail than any published source. Furthermore, the microfilm record is the only source of individual bank data from the Reports of Earnings and Dividends.

Data in the microfilm collection are not available equally for both State Member and National Banks. For State Member Banks, June and December Reports of Condition were microfilmed for each year during the Great Depression. For National Banks, however, only selected dates were microfilmed. Those dates are December 1929, 1931, 1933, and annually thereafter.

Over an eight-year period we hand-entered and checked data for all available banks in this collection between the years 1929 and 1935 . We used existing National Bank charter numbers and constructed State Bank charter numbers to link each set of individual bank records across time. The final data set includes 66,316 bank records from 10,092 banks. Since the present paper is only concerned with events prior to the Bank Holiday of March 1933, we restrict ourselves to bank data reported on December 31, 1929 and December 31, 1931. Therefore the present analysis incorporates 14,410 bank records from 7,931 banks.

Each bank record contains roughly 100 data fields. These fields include not only typical consolidated balance sheet items, but also earnings and expense information from bank income statements. Additionally, we gathered information from detailed schedules of asset, liability, earnings, and expense compositions of each bank. Call reports also contain information on the number of branches operated by each bank. Table A1 lists the fields we entered.

We also gathered bank structure data (that is, data on individual bank failures, mergers, acquisitions, name changes, etc ...) linking banks to exit events including record dates of failures. The structure data for National Banks was handentered from the unpublished Comptroller of the Currency structure records located in that agency's archives. Structure data for State Member banks was hand-entered from Rand McNally's Banker's Directory. Our structure data contain almost 70 different ways a bank can exit the data set, ranging from all imaginable types of mergers and acquisitions to relatively simple voluntary liquidations and receiverships (which, together, we term failures). For our present work we only utilize data on voluntary liquidations and receiverships.

Our data on failures for Fed member banks identify the date at which banks were placed into receivership or were closed by voluntary liquidation. All results reported below combine receivership and voluntary liquidation into a single measure of bank failure. Results not reported here show slight differences in results for the two categories taken separately, and thus little advantage to analyzing them separately.

Many banking studies have had to rely on bank suspension rather than liquidation as their measure of bank failure. Suspensions are typically employed because data on bank failures, both for numbers and deposits of failed banks, are not readily available at the regional or national level, especially for observations at greater than annual frequency. Data on suspensions can provide a misleading picture of bank failure. In some cases, suspensions were temporary and suspended banks quickly reopened (Calomiris, 1992). Furthermore, suspension is not consistently defined in the literature. The Federal Reserve series on bank "suspensions," published in Banking and Monetary Statistics (1976), mixes suspensions (of state-chartered banks) and liquidations (of national banks).

The distinction between suspension and fail- 
TAble A1-Reports of Condition And Reports of EARnings And ExPenses Fields

\begin{tabular}{|c|c|}
\hline General Information & Acceptances of this Bank Purchased or Discounted \\
\hline Date & All Other Loans \\
\hline FR District & Schedule of Loans: Memoranda \\
\hline State & Loans Secured by U.S. Government Securities in Items \\
\hline National Bank & E4 and E5 \\
\hline $\begin{array}{l}\text { Central Reserve City Bank } \\
\text { Other Reserve City Bank }\end{array}$ & Total Loans Eligible for Rediscount \\
\hline County & Schedule of Bills Payable and Rediscounts \\
\hline City & Bills Payable from Federal Reserve Bank \\
\hline Name & Bills Payable from Reconstruction Finance Corp \\
\hline Charter Number (National Banks) & Notes and Bills Rediscounted with Federal Reserve Bank \\
\hline Assets & Notes and Bills Rediscounted with Reconstruction \\
\hline Loans and Discounts & Finance Corp \\
\hline Overdrafts & Due from Member Banks and Trust Companies in New York \\
\hline U.S. Government Securities Owned & Due from Member Banks and Trust Companies in Chicago \\
\hline Other Bonds, Stocks, and Securities Owned & Due from Member Banks and Trust Companies Elsewhere \\
\hline Customers' Liability on Account of Acceptances & in United States \\
\hline Banking House and Furniture/Fixtures & $\begin{array}{l}\text { Due from Nonmember Banks and Trust Companies in } \\
\text { New York }\end{array}$ \\
\hline Real Estate Owned Other Than Banking House & Due from Nonmember Banks and Trust Companies in Chicago \\
\hline Reserve with Fed & Due from Nonmember Banks and Trust Companies \\
\hline $\begin{array}{l}\text { Cash and Due From Banks } \\
\text { Outside Checks and Other Cash Items }\end{array}$ & Elsewhere in United States \\
\hline Redemption Fund with U.S. Treasury & Schedule of Deposits \\
\hline Acceptances of Other Banks, Bills of Exchange, or Drafts Sold & State, County, and Municipal Demand Deposits \\
\hline Securities Borrowed & State, County, and Municipal Time Deposits \\
\hline Other Assets & \\
\hline Total Assets & Income \\
\hline & Interest and Discount on Loans \\
\hline Liabilities & Interest and Dividends on Investments \\
\hline Demand Deposits & Interest on Balances with Other Banks \\
\hline Time Deposits & Domestic Exchange and Collection Charges \\
\hline U.S. Government Deposits & Foreign Exchange Department \\
\hline Due to Banks & Commissions and Earnings from Insurance and Real \\
\hline Circulating Notes Outstanding & Estate Loans \\
\hline Bills Payable & Trust Department \\
\hline Rediscounts & Profits on Securities Sold \\
\hline Capital & Service Charges on Deposit Accounts \\
\hline Surplus & Other Earnings \\
\hline Net Undivided Profits & \\
\hline Reserves for Dividends or Contingencies & Expenses \\
\hline Preferred Stock Retirement Fund & Salaries and Wages \\
\hline Reserve for Dividend Payable in Common Stock & Interest and Discount on Borrowed Money \\
\hline Other Liabilities & Interest on Bank Deposits \\
\hline & Interest on Demand Deposits \\
\hline Other Information & Interest on Time Deposits \\
\hline Liabilities of Officers and Directors as Payers & Interest and Discount on Borrowed Money \\
\hline Branches and Branch Offices in Corporate Limits of Head Office City & Taxes \\
\hline Branches and Branch Offices Elsewhere in United States & Other Expenses \\
\hline Schedule of Loans & Net Earnings \\
\hline Acceptances of Other Banks, Payable in the United States, Owned & Recoveries \\
\hline by This Bank & Recoveries on Loans and Discounts \\
\hline Notes, Bills, Acceptances, and Other Instruments Evidencing Loans & Recoveries on Bonds and Securities \\
\hline Payable in Foreign Countries & Recoveries on All Other \\
\hline Commercial Paper Bought in Open Market & \\
\hline Loans to Banks and Trust Companies on Securities & Losses \\
\hline All Other Loans to Banks and Trust Companies & Losses on Loans and Discounts \\
\hline Loans on Securities to Brokers and Dealers in New York City & Losses on Bonds and Securities \\
\hline Loans on Securities to Brokers and Dealers Outside New York City & Losses on Banking House, Furniture, and Fixtures \\
\hline Loans on Securities to Others & Losses on Foreign Exchange \\
\hline $\begin{array}{l}\text { Real Estate Loans, Mortgages, Deeds of Trust, and Other Liens on } \\
\text { Real Estate on Farm Land }\end{array}$ & Losses on Other \\
\hline $\begin{array}{l}\text { Real Estate Loans, Mortgages, Deeds of Trust, and Other Liens on } \\
\text { Other Real Estate }\end{array}$ & Net Operating Earnings \\
\hline
\end{tabular}


ure is particularly important during early 1933 - a time when virtually all banks "suspended" operations during state and national bank holidays, but during which only some of those banks failed. Developing a database on bank failures makes it possible to investigate the role of contagion in bank failures during early 1933, which is not possible using suspension data. Understanding the determinants of the large number of bank failures in early 1933 is a crucial and omitted part of the history of bank distress during the Depression.

The main obstacle to collecting comprehensive bank failure data at high frequency is the absence of readily available information for non-Fed member banks (hereinafter referred to as nonmember banks). Given that our data on balance sheets and income statements only include member banks, this limitation was not a problem from the standpoint of analyzing the failure experiences of banks in our sample.

Even though our sample includes nearly all Fed member banks, one can question whether that sample of banks is representative, given the large number of excluded nonmember banks. It is worth noting that nonmember banks were much smaller on average than member banks, so their number exaggerates their importance. As of June 30, 1929, nonmember banks comprised 15,797 of the 24,504 banks in existence (of which 7,530 were national banks and 1,177 were state-chartered member banks). But nonmember banks only accounted for 27 percent of banking system deposits ( $\$ 13.2$ billion of the total $\$ 49.0$ billion). ${ }^{7}$ The broad patterns of growth of member and nonmember banks are similar in loans and deposits, although nonmember banks grew more slowly in the period 1921-1929 (loans grew by an average of 27 percent for nonmember banks, as opposed to 42 percent for member banks) and shrank more quickly from 1929 to 1932 (nonmember banks' loans declined by an average of 48 percent, compared to a 35 percent decline for member banks). These patterns reflect in large part the consolidation wave produced by agricultural distress in the 1920's (which was reflected in the greater growth of member banks) and the greater continuing vulnerability of small, non-

\footnotetext{
${ }^{7}$ Data are from Federal Reserve Board (1976, pp. 2223)
}

member banks in the 1930's. Exit rates were higher for nonmember banks than for member banks during the Depression; nonmember banks fell as a proportion of total banks from 63 percent of the number of banks in June 1929 to 57 percent by June $1933 .{ }^{8}$ Nevertheless, our sample of member banks includes a large number of failed institutions. There were 7,498 Fed member banks in our sample as of the end of December 1929. 1,528 banks in our sample (including banks that entered after December 1929) had failed by the end of 1933 (that is, were placed into receivership or were voluntarily liquidated).

Thus our sample of member banks comprises a large segment of the banking sector, but the exclusion of nonmember banks reduces the bank failure rate. From an aggregate standpoint, the variation over time in bank failures apparent in Figure 1 of our paper using our definition (the hazard rate of survival for member banks) is quite similar to the pattern when one defines the failure process using the deposits of all suspended commercial banks). In particular, our measured raw hazard rate of failure increases markedly during the episodes of banking crisis identified by Friedman and Schwartz (1963).

Our analysis of bank failure risk for individual banks is for 1930-1933. The beginning of this period is dictated by the starting date for our balance sheet data (i.e., December 1929). The end of this period is dictated by the events of early 1933, which saw the suspension of bank operations through bank holidays, first at the state level via a series of actions by the various state authorities in February and March 1933, and finally at the federal level in March 1933. March 1933 was the end of the last wave of sudden bank failure during the Depression, the time when the United States departed from the gold standard, and marked the beginning of the recovery of 1933-1937.

The number of banks that failed in the legal sense (i.e., that were placed into receivership or voluntarily liquidated) in March 1933 understates the true number of failures at that time. Many banks that had suspended in early 1933 remained in limbo until the regulatory authorities and the RFC determined whether to assist

\footnotetext{
${ }^{8}$ Data are from Wicker (1996, pp. 15), derived from Federal Reserve Board (1976, pp. 22-23, 72, 74).
} 
them and whether to permit them to become members of the FDIC. The large number of bank failures in late 1933 and early 1934, therefore, might be best viewed as delayed reactions to the shocks of early 1933. We discuss this problem in more detail in our empirical analysis of bank failures. ${ }^{9}$

\section{County-Level Bank Characteristics}

Our county-level bank data come from the Federal Deposit Insurance Corporation (FDIC) Data on Banks in the United States, 1920-1936 [Intra-university Consortium for Political and Social Research (ICPSR) study number 00007]. This source provides, for state and national banks, jointly and individually, bank deposits and the number of banks in each county annually. The data set also reports the number of banks and deposits in banks that suspended each year, also at the county level. For some reason, counties in Wyoming are not included in this data set, and so any empirical work that relies on this source excludes Wyoming counties.

The FDIC data allow us to check our distress specification more accurately against previous work by using suspension rates at the county level as a dependent variable in addition to failures (at the bank level). Furthermore, the FDIC data allow us to model deposit flows at the county level for a more robust interpretation of bank distress. The FDIC data yield a measure of the size of the banking sector at the county level that captures all banks, not only Federal Reserve member banks. We use county-level measures of deposits and suspensions in our county-level regression analysis of bank distress. In those regressions, explanatory variables aggregate individual bank characteristics to the county level by simple averaging (rather than weighting by size). We use simple averaging at the county level to correct for the undersampling of small banks that results from our reliance on Fed member banks.

\footnotetext{
${ }^{9}$ Over the course of 1933, banks would be examined and either permitted to survive or forced to close. For discussions of bank resolution policy during 1933, see Cyril B. Upham and Edwin Lamke (1934), Susan E. Kennedy (1973), Wicker (1996), and Mason (2001b).
}

\section{Other County-Level Characteristics}

County-level characteristic data come from Historical, Demographic, Economic, and Social Data: The United States, 1790-1970 [(ICPSR) study number 00003]. This source yields county data on, among other items, unemployment rates, acres of land devoted to agricultural production, the value of agricultural production, land devoted to and value derived from different agricultural product types, the number of farms in different size categories, and the value of agricultural investment. These data help control for different asset classes, relative values of bank portfolios, and other exogenous factors that may affect bank distress.

The county characteristic data from the ICPSR are coded from decadal U.S. census data. We drew upon ICPSR data from 1920, 1930, and 1940 so we could test various specifications including mixtures of levels and growth rates.

\section{State-Level Economic Data}

State characteristic data are included to incorporate higher-frequency time-series data into our analysis of the causes and effects of bank distress. However, higher frequency sometimes comes at the expense of more geographical aggregation.

We felt it was important to include available measures of local distress that control for heterogeneity in economic conditions across the United States at different times during the Great Depression. Bradstreet's Weekly published a monthly summary of building activity in 215 major U.S. cities during the period of the Great Depression, broken down by new construction and alterations. We include the total series as a monthly indicator of economic conditions in the local community. When our survival model is restricted to banks located in the 215 major cities, this variable includes building permits at the city level. When the survival model includes all Fed member banks, building permits are aggregated to the state level.

An important indicator of local economic conditions is liabilities of failed businesses at the local level. However, there is no single series of liabilities of failed businesses for the entire period comprising the Great Depression. We therefore collected a state-level monthly 
series of the number and liabilities of failed businesses from Bradstreet's Weekly December 1928 through June 1931 and a regional quarterly series from Dun's Review first quarter 1931 through fourth quarter 1932.

To construct quarterly state-level measures of these variables at the state level for the second two quarters of 1931, and for 1932, we combined annual state-level figures from Dun's Review with the quarterly region-level figures. Specifically, for the last two quarters of 1931, we allocated the total liabilities of failed firms to each of the two quarters by assuming that the relative proportion of failures in each quarter was the same within any region. We used the same method to allocate each state's 1932 failures into the four quarters of that year. We use the overlapping period during the first two quarters of 1931 to calibrate the estimation.

We also experimented with annual state income measures from John A. Slaughter (1937), but these did not prove significant or robust.

\section{National Economic Data}

Although we were able to obtain state-level data on business failures at quarterly frequency, and state-level data on building permits at monthly frequency, we felt it was desirable to include additional monthly economic data in the specification to capture high-frequency fundamental changes. Additional monthly data are only available at the national level.

We include three national economic variables in our specifications. The first of these is an index of agricultural prices published in The Farm Real Estate Situation (U.S. Department of Agriculture, various issues). We initially gathered seven price series on individual commodity groups including: grains; fruits and vegetables; meat animals; dairy products; poultry products; cotton and cotton seed; and all groups (30 items). We tested these both individually and interacted with our county agriculture characteristic data. Only the national overall index proved significant and robust in our specifications, and is included in our final results.

The second national economic variable included in our specification is liabilities of failed businesses (outside the banking sector). The source of this series is Dun's Review, which published a continuous national series throughout our period.

Third, we include Treasury bond yields that control for market conditions affecting bank investments, particularly relating to the value of U.S. government securities in bank portfolios. Our treasury yields come from Banking and Monetary Statistics, and reflect yields on “... non-callable bonds or callable bonds selling below call price, in other words, bonds which are free to reflect changes in interest rates" (p. 428). We also experimented with corporate bonds and the Baa spread over Treasuries, though these were neither significant nor robust and are excluded from our present specification.

\section{Other Data for Measuring Distress}

We include variables in our specifications that control for several widely held sources of bank distress. These include indicators of alleged national panic episodes as reported by Friedman and Schwartz (1963), indicators of alleged regional panics reported by Wicker (1980; 1996), an indicator for the Chicago bank panic discussed at length by James (1938) and Calomiris and Mason (1997), and a constructed measure of nearby bank failures.

Friedman and Schwartz national panics are captured by indicator variables that take the value of 1 for all banks during panic months and 0 otherwise. The panic periods we adopt from Friedman and Schwartz and their associated dates are: November 1930-January 1931, MayJune 1931, September-November 1931, and separate indicators for January, February, and March 1933. Robustness checks confirmed that extending or contracting the panic windows for the 1930 or 1931 episodes reduced the magnitude and significance of the indicator variables in our specifications.

Wicker regional panics are captured by indicator variables that take the value of 1 for banks in affected regions during panic periods and 0 otherwise. The panic periods we adopt from Wicker and their associated states and dates in our specification are: November 1930-January 1931 for banks in Tennessee, Kentucky, Ar- 
kansas, North Carolina, and Mississippi, April-July 1931 for banks in Illinois and Ohio, and September-October 1931 for banks in West Virginia, Ohio, Missouri, Illinois, and Pennsylvania.

The Chicago bank panic is captured by an indicator variable taking the value of 1 for banks in the city of Chicago during June 1932 and 0 otherwise.

Nearby bank failures are characterized by using our member bank data (described in detail above) to aggregate deposits in failed banks at the state level for each monthly period. We experimented with various failure windows and lag specifications on deposits in nearby bank failures. Contemporaneous monthly data (excluding each failed bank's own deposits where applicable) yielded the most significant and robust results.

\section{REFERENCES}

Allen, Franklin and Gale, Douglas. "Financial Contagion." Journal of Political Economy, January 2000, 108(1), pp. 1-33.

Anari, Ali; Kolari, James W. and Mason, Joseph R. "Bank Asset Liquidation and the Propagation of the U.S. Great Depression." Journal of Money, Credit, and Banking (forthcoming). This is a revised version of Wharton Financial Institutions Center (Philadelphia, PA) Working Paper No. 0235, August 2002.

Bernanke, Ben S. and James, Harold. "The Gold Standard, Deflation, and Financial Crisis in the Great Depression: An International Comparison," in R. Glenn Hubbard, ed., Financial markets and financial crises. Chicago: University of Chicago Press, 1991, pp. 33-68.

Bradstreet's Weekly. New York: Bradstreet Company, various issues.

Calomiris, Charles W. "Do Vulnerable Economies Need Deposit Insurance? Lessons from U.S. Agriculture in the 1920s," in Philip L. Brock, ed., If Texas were Chile: A primer on bank regulation. San Francisco: Sequoia Institute, 1992, pp. 237-349, 45058.

- U.S. bank deregulation in historical perspective. Cambridge: Cambridge University Press, 2000.
Calomiris, Charles W. and Gorton, Gary. "The Origins of Banking Panics: Models, Facts, and Bank Regulation," in R. Glenn Hubbard, ed., Financial markets and financial crises. Chicago: University of Chicago Press, 1991, pp. 107-73.

Calomiris, Charles W. and Mason, Joseph R. "Contagion and Bank Failures During the Great Depression: The June 1932 Chicago Banking Panic." American Economic Review, December 1997, 87(5), pp. 86383.

. "Causes of Bank Distress During the Great Depression." National Bureau of Economic Research (Cambridge, MA) Working Paper No. 7919, September 2000.

- "The Consequences of Bank Distress During the Great Depression." American Economic Review, June 2003a, 93(3), pp. 937-47.

. "Causal Links Among Bank Distress, Asset Values and Corporate Distress During the Great Depression." Working paper, Columbia University, 2003b.

Calomiris, Charles W. and Wheelock, David C. "The Failures of Large Southern Banks During the Great Depression." Working paper, Columbia University, 1995.

Calomiris, Charles W. and Wilson, Berry. "Bank Capital and Portfolio Management: The 1930s 'Capital Crunch' and Scramble to Shed Risk." Journal of Business (forthcoming). This is a revised version of National Bureau of Economic Research (Cambridge, MA) Working Paper No. 6649, July 1998.

Carlson, Mark. "Are Branch Banks Better Survivors? Evidence from the Depression Era." Federal Reserve Board Working Paper No. 2001-51, November 2001.

Comptroller of the Currency. Record book of changes to nationally chartered banks [unpublished].

-Diamond, Douglas W. and Dybvig, Phillip H. "Bank Runs, Deposit Insurance, and Liquidity." Journal of Political Economy, June 1983, 91(3), pp. 401-19.

Diamond, Douglas W. and Rajan, Raghuram. "Liquidity Shortage and Banking Crises." National Bureau of Economic Research (Cambridge, MA) Working Paper No. 8937, May 2002. 
Dun's Review. Various issues.

Federal Deposit Insurance Corporation Data on Banks in the United States, 1920-1936. Intra-university Consortium for Political and Social Research Study \#00007. Ann Arbor, MI: University of Michigan and Intra-university Consortium for Political and Social Research.

Federal Reserve Board. Banking and monetary statistics, 1914-1941. Washington, DC: Board of Governors, 1976.

Friedman, Milton and Schwartz, Anna J. A monetary history of the United States, 18671960. Princeton, NJ: Princeton University Press, 1963.

. "The Failure of the Bank of United

States: A Reappraisal: A Reply." Explorations in Economic History, April 1986, 23(2), pp. 199-204.

-Grossman, Richard S. "The Shoe That Didn't Drop: Explaining Banking Stability During the Great Depression." Journal of Economic History, September 1994, 54(3), pp. 654-82.

Historical, Demographic, Economic, and Social Data: The United States, 1790-1970. Intrauniversity Consortium for Political and Social Research Study \#00003. Ann Arbor, MI: University of Michigan and Intrauniversity Consortium for Political and Social Research.

- Imbens, Guido W. "Transition Models in a NonStationary Environment." Review of Economics and Statistics, November 1994, 76(4), pp. 703-20.

James, F. Cyril. The growth of Chicago banks, volume II. New York: Harper, 1938.

Kennedy, Susan E. The banking crisis of 1933. Lexington, KY: Kentucky University Press, 1973.

Kiefer, Nicholas M. "Economic Duration Data and Hazard Functions." Journal of Economic Literature, June 1988, 26(2), pp. 646-79.

Lancaster, Tony. The econometric analysis of transition data. Cambridge: Cambridge University Press, 1990.

Lucia, Joseph. "The Failure of the Bank of United States: A Reappraisal." Explorations in Economic History, October 1985, 22(4), pp. 402-16.

Mason, Joseph R. "American Banks During the Great Depression: A New Research Agenda."
Federal Reserve Bank of St. Louis Review, May/June 1998, 80(3), pp. 151-52.

- "Do Lender of Last Resort Policies

Matter? The Effects of Reconstruction Finance Corporation Assistance to Banks During the Great Depression." Journal of Financial Services Research, September 2001a, 20(1), pp. 77-95. - "Reconstruction Finance Corporation Assistance to Financial Intermediaries and Commercial and Industrial Enterprise in the U.S., 1932-1937," in Stijn Claessens, Simeon Djankov, and Oshoka Mody, eds., Resolving financial distress. Washington, DC: World Bank, 2001b, pp. 167-204.

O'Brien, Anthony P. "The Failure of the Bank of United States: A Defense of Joseph Lucia." Journal of Money, Credit, and Banking, August 1992, 24(3), pp. 374-84.

Ramirez, Carlos D. "Did Branch Banking Restrictions Increase Bank Failures? Evidence from Virginia and West Virginia in the Late 1920s." Working paper, George Mason University, 2000.

Rand McNally Banker's Directory. New York: Rand McNally \& Co., various issues.

Reports of Condition. Washington, DC: Board of Governors of the Federal Reserve System. Unpublished microfilm archive, various call dates.

Reports of Earnings and Dividends. Washington, DC: Board of Governors of the Federal Reserve System. Unpublished microfilm archive, various call dates.

Slaughter, John A. Income received in the various states, 1929-1935. New York: National Industrial Conference Board Studies, No. 234, 1937.

Temin, Peter. Did monetary forces cause the Great Depression? New York: W.W. Norton, 1976.

- Lessons from the Great Depression. Cambridge, MA: MIT Press, 1989.

Trescott, Paul B. "The Behavior of the CurrencyDeposit Ratio during the Great Depression: A Comment." Journal of Money, Credit, and Banking, August 1984, 16(3), pp. 36265.

. "The Failure of the Bank of United States, 1930." Journal of Money, Credit, and Banking, August 1992, 24(3), pp. $384-$ 99. 
U.S. Department of Agriculture. The farm real estate situation. Washington, DC: U.S. Government Printing Office, various issues.

Upham, Cyril B. and Lamke, Edwin. Closed and distressed banks. Washington, DC: Brookings Institution, 1934.

-White, Eugene N. "A Reinterpretation of the Banking Crisis of 1930." Journal of Economic History, March 1984, 44(1), pp. 119 38.
-Wicker, Elmus. "A Reconsideration of the Causes of the Banking Panic of 1930." Journal of Economic History, September 1980, 40(3), pp. 571-83.

The banking panics of the Great Depression. Cambridge: Cambridge University Press, 1996.

-Wigmore, Barrie A. "Was the Bank Holiday of 1933 a Run on the Dollar Rather than the Banks?" Journal of Economic History, September 1987, 47(3), pp. 739-56. 


\section{This article has been cited by:}

1. R. Iyer, J.-L. Peydro. 2011. Interbank Contagion at Work: Evidence from a Natural Experiment. Review of Financial Studies 24:4, 1337-1377. [CrossRef]

2. C. O. Brown, I. S. Dinc. 2011. Too Many to Fail? Evidence of Regulatory Forbearance When the Banking Sector Is Weak. Review of Financial Studies 24:4, 1378-1405. [CrossRef]

3. Robert D. Baller, Phil Levchak, Mark Schultz. 2010. "The Great Transformation" and Suicide: Local and Long-Lasting Effects of 1930 Bank Suspensions. Suicide and Life-Threatening Behavior 40:6, 574-586. [CrossRef]

4. M. Bordo, J. Landon-Lane. 2010. The banking panics in the United States in the 1930s: some lessons for today. Oxford Review of Economic Policy 26:3, 486-509. [CrossRef]

5. C. W. Calomiris. 2010. The political lessons of Depression-era banking reform. Oxford Review of Economic Policy 26:3, 540-560. [CrossRef]

6. P. Fishback. 2010. US monetary and fiscal policy in the 1930s. Oxford Review of Economic Policy 26:3, 385-413. [CrossRef]

7. N. Crafts, P. Fearon. 2010. Lessons from the 1930s Great Depression. Oxford Review of Economic Policy 26:3, 285-317. [CrossRef]

8. Qi Chen, Itay Goldstein, Wei Jiang. 2010. Payoff complementarities and financial fragility: Evidence from mutual fund outflows\#. Journal of Financial Economics 97:2, 239-262. [CrossRef]

9. EDUARDO LEVY-YEYATI, MARÍA SOLEDAD MARTÍNEZ PERÍA, SERGIO L. SCHMUKLER. 2010. Depositor Behavior under Macroeconomic Risk: Evidence from Bank Runs in Emerging Economies. Journal of Money, Credit and Banking 42:4, 585-614. [CrossRef]

10. Paul Goldsmith-Pinkham, Tanju Yorulmazer. 2010. Liquidity, Bank Runs, and Bailouts: Spillover Effects During the Northern Rock Episode. Journal of Financial Services Research 37:2-3, 83-98. [CrossRef]

11. MARK CARLSON. 2010. Alternatives for Distressed Banks during the Great Depression. Journal of Money, Credit and Banking 42:2-3, 421-441. [CrossRef]

12. Barrie A. WigmoreA comparison of federal financial remediation in the great depression and 2008-2009 27, 255-303. [CrossRef]

13. Franklin Allen, Ana Babus, Elena Carletti. 2009. Financial Crises: Theory and Evidence. Annual Review of Financial Economics 1:1, 97-116. [CrossRef]

14. F. Akiyoshi. 2009. Banking panics, bank failures, and the lender of last resort: the Showa Depression of 1930-1932. Oxford Economic Papers 61:4, 776-800. [CrossRef]

15. Mason Gaffney. 2009. 3. Money, Credit, and Crisis. American Journal of Economics and Sociology 68:4, 983-1038. [CrossRef]

16. Huberto M. Ennis, , Todd Keister. 2009. Bank Runs and Institutions: The Perils of InterventionBank Runs and Institutions: The Perils of Intervention. American Economic Review 99:4, 1588-1607. [Abstract] [View PDF article] [PDF with links]

17. Luc Laeven, Ross Levine. 2009. Bank governance, regulation and risk taking\#. Journal of Financial Economics 93:2, 259-275. [CrossRef]

18. MASAMI IMAI. 2009. Political Influence and Declarations of Bank Insolvency in Japan. Journal of Money, Credit and Banking 41:1, 131-158. [CrossRef]

19. Charles W Calomiris. 2009. The Subprime Turmoil: What's Old, What's New, and What's Next. The Journal of Structured Finance 15:1, 6-52. [CrossRef] 
20. Gary Richardson. 2007. The Check is in the Mail: Correspondent Clearing and the Collapse of the Banking System, 1930 to 1933. The Journal of Economic History 67:03. . [CrossRef]

21. Arnaldo Canziani. 2007. Survival and Growth in Joint-Stock Banking Oligopolies. Lessons from the Crises of 1917-1923 on the Role of Competitors and Politics. Accounting, Business \& Financial History 17:1, 129-163. [CrossRef]

22. Gary RichardsonQuarterly data on the categories and causes of bank distress during the Great Depression, 1929-1933 25, 69-147. [CrossRef]

23. GIOVANNI FEDERICO. 2005. Not Guilty? Agriculture in the 1920s and the Great Depression. The Journal of Economic History 65:04. . [CrossRef]

24. Joseph R. Mason. 2005. A Real Options Approach to Bankruptcy Costs: Evidence from Failed Commercial Banks During the 1990s. The Journal of Business 78:4, 1523-1554. [CrossRef]

25. KRIS JAMES MITCHENER. 2005. Bank Supervision, Regulation, and Instability During the Great Depression. The Journal of Economic History 65:01. . [CrossRef]

26. Charles W. Calomiris, Berry Wilson. 2004. Bank Capital and Portfolio Management: The 1930s "Capital Crunch" and the Scramble to Shed Risk. The Journal of Business 77:3, 421-455. [CrossRef] 